\title{
Thalamus-Derived Molecules Promote Survival and Dendritic Growth of Developing Cortical Neurons
}

\author{
Haruka Sato, ${ }^{1}$ Yuma Fukutani, ${ }^{1}$ Yuji Yamamoto, ${ }^{1}$ Eiichi Tatara, ${ }^{1}$ Makoto Takemoto, ${ }^{1}$ Kenji Shimamura, ${ }^{2}$ \\ and Nobuhiko Yamamoto ${ }^{1}$ \\ ${ }^{1}$ Laboratory of Cellular and Molecular Neurobiology, Graduate School of Frontier Biosciences, Osaka University, Suita, Osaka 565-0871, and ${ }^{2}$ Department of \\ Brain Morphogenesis, Institute of Molecular Embryology and Genetics, Kumamoto University, Kumamoto 860-0811, Japan
}

The mammalian neocortex is composed of various types of neurons that reflect its laminar and area structures. It has been suggested that not only intrinsic but also afferent-derived extrinsic factors are involved in neuronal differentiation during development. However, the role and molecular mechanism of such extrinsic factors are almost unknown. Here, we attempted to identify molecules that are expressed in the thalamus and affect cortical cell development. First, thalamus-specific molecules were sought by comparing gene expression profiles of the developing rat thalamus and cortex using microarrays, and by constructing a thalamus-enriched subtraction cDNA library. A systematic screening by in situ hybridization showed that several genes encoding extracellular molecules were strongly expressed in sensory thalamic nuclei. Exogenous and endogenous protein localization further demonstrated that two extracellular molecules, Neuritin-1 (NRN1) and VGF, were transported to thalamic axon terminals. Application of NRN1 and VGF to dissociated cell culture promoted the dendritic growth. An organotypic slice culture experiment further showed that the number of primary dendrites in multipolar stellate neurons increased in response to NRN1 and VGF, whereas dendritic growth of pyramidal neurons was not promoted. These molecules also increased neuronal survival of multipolar neurons. Taken together, these results suggest that the thalamus-specific molecules NRN1 and VGF play an important role in the dendritic growth and survival of cortical neurons in a cell type-specific manner.

\section{Introduction}

The neocortex is composed of various cell types having distinct morphology, connection patterns, and physiological properties (Ramón y Cajal, 1899; McConnell, 1989; Hevner, 2007; Molyneaux et al., 2007). How cortical neurons differentiate into specific cell types during development is one of the most interesting issues in neurobiology. Developmental studies in the mammalian neocortex have shown that intrinsic factors, including particular transcription factors, are necessary for cell type specification (Grove and Fukuchi-Shimogori, 2003; Molyneaux et al., 2007; O'Leary and Sahara, 2008). The transcription factors Tbr1, Ctip2, Satb2, and Cux2, which are expressed in specific layers of the developing cortex, contribute to laminar fate determination (Alcamo et al., 2008; Chen et al., 2008; Cubelos et al., 2008; Bedogni et al., 2010), while Emx2, Pax6, and Coup-tf1 are involved in area patterning by being expressed in a graded fashion (Bishop et al.,

Received Jan. 10, 2012; revised July 18, 2012; accepted Sept. 3, 2012.

Author contributions: M.T. and N.Y. designed research; H.S., Y.F., Y.Y., E.T., M.T., and N.Y. performed research; H.S., Y.F., Y.Y., E.T., and K.S. analyzed data; H.S., K.S., and N.Y. wrote the paper.

This work was supported by Grants-in-Aid for Scientific Research on Innovative Areas "Mesoscopic Neurocircuitry" (No. 23115102) of the Japanese Ministry of Education, Culture, Sports, Science and Technology to N.Y., and for Scientific Research (B) (No. 20300110 and 23300118) of Japan Society for the Promotion of Science (JSPS) to N.Y. We thank Dr. lan Smith for critical reading of this manuscript.

The authors declare no competing financial interests.

Correspondence should be addressed to Nobuhiko Yamamoto, Laboratory of Cellular and Molecular Neurobiology, Graduate School of Frontier Biosciences, Osaka University, 1-3 Yamadaoka, Suita, Osaka 565-0871, Japan. E-mail: nobuhiko@fbs.osaka-u.ac.jp.

DOI:10.1523/JNEUROSCI.0293-12.2012

Copyright $\odot 2012$ the authors $\quad 0270-6474 / 12 / 3215388-15 \$ 15.00 / 0$
2000; Mallamaci et al., 2000; Armentano et al., 2007; O’Leary et al., 2007).

Extrinsic factors produced by the surrounding cells also affect cellular differentiation. For instance, environmental molecules such as growth factors, extracellular matrix proteins, and neurotrophic factors can regulate cell type specification and morphological differentiation of cortical neurons (Ferri and Levitt, 1995; McAllister et al., 1995). Afferent input is also an important source of extrinsic factors. It has been shown that afferent-derived molecules regulate neurogenesis and synapse formation in their target region (Huang and Kunes, 1996; Sanes and Lichtman, 2001). Thalamic fibers are the major input into the neocortex and may influence differentiation of cortical cells (O'Leary, 1989). In support of this view, the finding has been reported that grafted cortical neurons exhibit characteristics of the host cortical area regardless of their origins (Schlaggar and O'Leary, 1991). It has also been demonstrated that duplicate somatosensory areas are formed in association with additional thalamic inputs (FukuchiShimogori and Grove, 2001). Thalamic fibers may also affect the composition of cell types. The thalamocortical recipient layer, layer 4 , in the primary sensory areas receives extensive axonal projections from sensory thalamic nuclei. It is enriched with spiny stellate neurons with multipolar dendritic morphology, whereas other layers are mainly composed of pyramidal neurons. An intriguing hypothesis is that thalamus-derived factor(s) promote the survival and morphological differentiation of a subset of cortical neurons. However, such factor(s) have yet been identified.

To address this issue, we searched for extracellular molecules that are specifically expressed in the thalamus, but not in the 
cortex, in the postnatal rodent brain. We then examined whether the candidate molecules are transported to axon terminals and analyzed their effects on cortical cell development in vitro. The results reveal that NRN1 and VGF are expressed strongly in the thalamus and promote the survival and dendritic growth of a subpopulation of cortical neurons.

\section{Materials and Methods}

Animals. Sprague Dawley rats of either sex were used for the construction of a subtraction cDNA library, microarray analysis, and in situ hybridization and to establish dissociated cell cultures (Nihon animals, CLEA Japan and SLC Japan). ICR mice of either sex were used for in utero electroporation, the subsequent production of organotypic slice cultures, and immunohistochemistry (SLC Japan). The day of vaginal plug detection was designated as embryonic day 0 (E0), and the day of birth as postnatal day $0(\mathrm{P} 0)$. All experiments were carried out under the Guidelines for Laboratory Animals of Osaka University and the Japan Neuroscience Society.

Microarray analysis. Whole brains were removed from P3 rats. Coronal slices (400 $\mu \mathrm{m}$ thickness) were cut with a microtome in ice-cold Hanks' solution. Blocks of the dorsal lateral geniculate nucleus (dLGN) in the thalamus and cortical slices containing layers $1-5$ of the somatosensory cortex were dissected with scissors under a trans-illuminating microscope (Fig. $1 \mathrm{~B}$ ). Eight pieces of the dLGN and three cortical slices were collected from which total RNAs were extracted (Total RNA Extraction Miniprep System; Viogene). Approximately 1.6 and $4.5 \mu \mathrm{g}$ of total RNA were obtained from the dLGN and cortical tissues, respectively. The dLGN- and cortex-derived RNAs (100 ng each) were amplified with two consecutive rounds of linear in vitro transcription and labeled with a fluorescent dye. Hybridization solutions containing the labeled cRNAs were applied to the Rat Genome 2302.0 Array GeneChip (Affymetrix) and processed according to the manufacturer's protocol. Data from microarrays were normalized using robust multichip analysis (RMA).

Construction of a subtraction cDNA library. cDNAs were synthesized from the dLGN- and cortex-derived RNAs (140-170 ng; see above, Microarray analysis) with reverse transcriptase (BD SMART PCR CDNA Synthesis Kit; BD Biosciences), amplified with a primer (5'-AAGCAGTG GTAACAACGCAGAGT-3'), and digested with RsaI for the following hybridization. The dLGN DNAs were hybridized with an excess amount of the cortical DNAs (PCR Select cDNA Subtraction Kit; Clontech). Thereafter, unhybridized DNA fragments were further amplified, cloned into pGEM-T vectors (Promega), and stored as a subtraction cDNA library (thalamus minus cortex) (Zhong et al., 2004). Subtraction efficiency was analyzed by comparing the amount of cDNA for a constitutively expressed gene, Gapdh, in the subtracted and unsubtracted populations (Fig. 1D).

In situ hybridization. In situ hybridization and Nissl staining were performed as described previously (Zhong et al., 2004). DIG-labeled RNA probes were used for hybridization. For RNA probes of the genes identified from the microarray analysis, cDNA was produced by reverse transcription (Transcriptor High Fidelity cDNA Synthesis Kit; Roche) from total RNA prepared from the dLGN of P3 rat as described above (see Microarray analysis). cDNA fragments encoding Tmem192 (nucleotides 74-354; GenBank accession number AI071984, linked to nucleotides 577-53; FM142375), Nrn1 (nucleotides 1-1007; BC087582), Vgf (nucleotides 702-1321; NM_030997), Wnt2b (nucleotides 551-1629; NM_001191848), Angpt2 (nucleotides 349-1435; NM_134454), Col25a1 (nucleotides 662-1594; XM_001076940), and Ptprz1 (nucleotides 4968-5996; U04998) were isolated by RT-PCR and inserted into pGEM-T vectors. For the genes identified from the subtraction cDNA library, RNA probes were synthesized from cDNA fragments obtained from the library. To produce linearized templates for the synthesis of riboprobes, inserts were amplified by PCR using oligonucleotides containing T7 and SP6 promoter sequences. The PCR products were purified (Wizard SV Gel and PCR Clean-Up System; Promega), and in vitro transcription was carried out (DIG-RNA Synthesis Kit; Roche). Finally, the probes were purified with gel filtration columns (Quick Spin Columns; Roche) and kept at $-80^{\circ} \mathrm{C}$.
Rats were decapitated after anesthesia to obtain whole brains from postnatal animals (P0, P3, P7, and P14). Embryonic brains were taken from rat fetuses (E18) under deep anesthesia. The brains were fixed in $4 \%$ paraformaldehyde (PFA) in $0.1 \mathrm{M}$ phosphate buffer (PB) for $1 \mathrm{~h}$ at room temperature (RT) and then $2 \mathrm{~h}$ at $4^{\circ} \mathrm{C}$. After overnight incubation with sequential steps of 15 and $30 \%$ sucrose in Dulbecco's PBS, the brains were frozen and then cut into $20 \mu \mathrm{m}$ coronal sections with a cryostat. Sections were refixed in 4\% PFA in PB, washed in distilled water and 0.1 $\mathrm{M}$ triethanolamine (TEA), and then acetylated in $0.25 \%$ acetic acid in TEA and washed in PBS.

Prehybridization was carried out for $1 \mathrm{~h}$ in hybridization buffer $(50 \%$ formamide, $5 \%$ SDS, $5 \times$ saline-sodium phosphate-EDTA, $0.2 \mathrm{mg} / \mathrm{ml}$ tRNA), followed by hybridization overnight at $60^{\circ} \mathrm{C}$ in the same buffer containing $2 \mu \mathrm{g} / \mathrm{ml}$ of DIG-labeled RNA probe. After three washes in $50 \%$ formamide and $2 \times \mathrm{SSC}$ at $60^{\circ} \mathrm{C}$, the sections were blocked (blocking regent; Roche) for $1-4 \mathrm{~h}$ at $\mathrm{RT}$, and then incubated overnight at $4^{\circ} \mathrm{C}$ with alkaline phosphatase-conjugated anti-DIG antibody (1:2000; Roche). After five washes at RT, the color reaction was carried out at RT or $4^{\circ} \mathrm{C}$ in BM Purple (Roche). The reaction was terminated by immersing the sections in TE buffer (10 mM Tris-HCl, 1 mm EDTA, pH 8.0) overnight at $4{ }^{\circ} \mathrm{C}$, and the sections were then fixed in $4 \%$ PFA in PB for $15 \mathrm{~min}$. The sections were treated in 70, 80, 90, and 100\% ethanol and xylene and then embedded.

For Nissl staining, adjacent sections were used. These sections were immersed in $0.5 \%$ cresyl violet for several minutes and then subjected to the ethanol series and embedded.

Construction of expression vectors. For protein expression of the candidate genes, pCAG-Nrn1-Flag, pCAG-Vgf-human IgG Fc, and pCAGWnt2b-Flag were constructed as follows. cDNA fragments containing the coding region of mouse Nrn1 (GenBank accession number BC035531), Vgf (BC085134) and Wnt2b (BC119276) were obtained from commercially available plasmids (Open Biosystems).

A pair of primers (5'-CCCGTCGACCCACCATGGGACTTAAGTTGA

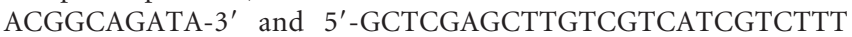
GTAGTCGCCCGCTGCTCTCACGGCCTG-3') was used to amplify the $\mathrm{N}$-terminal signal sequence of Nrn1 (nucleoetides 176-262; GenBank accession number BC035531) having a Flag tag. Another pair of primers (5' -CC TCGAGGCGGGCAAGTGTGATGCAGTC- $3^{\prime}$ and $5^{\prime}$-GGCGGCCGCTCA GAAGGAAAACCAGGTCGC-3') was used to amplify the remaining C-terminal region of Nrn1 (nucleotides 257-604; BC035531). These amplified DNA fragments were tandemly inserted into a pCAG to obtain the plasmid pCAG-N-terminal signal sequence of Nrn1-Flag-C-terminal region of Nrn1 (pCAG-Nrn1-Flag). To generate a Vgfexpression vector, the coding region of $V g f$ (nucleotides 469-2319; BC085134) was amplified with a pair of primers (5'-GTCGACGCCACCATGAAAACCTTCACGTTGC-3' and 5'GCGGCCGCCGGGCGGTGCAGCAGCA-3'). The amplified DNA fragment was inserted into pCAG containing a sequence encoding the $\mathrm{Fc}$ domain of human IgG to yield human IgG Fc fused to the C-terminal end of $\mathrm{VGF}$ (pCAG-Vgf-Fc). For the Wnt2b expression vector, the coding region of $W n t 2 b$ with a Flag tag at its $3^{\prime}$ end was amplified with a pair of primers (5'-CGTCGACCCACCATGCTGAAGCTGCAGGGTGAGG-3' and 5'-GG CGGCCGCCTACTTGTCGTCATCGTCTTTGTAGTCGGATCCGGTCT GGTCCAGCCACTCTGC-3'). The amplified DNA fragment was inserted into pCAG (pCAG-Wnt2b-Flag).

Preparation of candidate proteins. NRN1 and VGF were synthesized and purified as described previously (Maruyama et al., 2008). To produce the proteins, the expression plasmids were transfected into COS7 cells using the DEAE-dextran method (GE Healthcare Life Sciences). After several days, a supernatant containing NRN1-FLAG or VGF-Fc was collected and applied to an anti-FLAG column (ANTI-FLAG M2 Affinity Gel; Sigma-Aldrich) or a protein A column (Affi-Gel Protein A MAPS II Kit; Bio-Rad Laboratories), respectively. The eluate was desalted by gel filtration (HiTrap Desalting or PD-10 columns; GE Healthcare Life Sciences) with PBS and sterilized by filtration (Millex-GV; Millipore). Protein concentrations were determined by the Bradford method (Bio-Rad Protein Assay; Bio-Rad Laboratories). To assess the purity of each protein, the eluate was subjected to SDS-PAGE, after which Coomassie Brilliant Blue staining and Western blot analysis with mouse anti-FLAG antibody (1:1000, catalog no. F1804; Sigma-Aldrich) or rabbit anti- 
human Fc antibody (1:10000; catalog no. 309-005-008, Jackson ImmunoResearch Laboratories) were performed. The protein solutions were stored at $-80^{\circ} \mathrm{C}$. Commercially available recombinant NRN1 (catalog no. ab69755; Abcam) was used occasionally. These proteins were added to the culture medium at a final concentration of $20-1200 \mathrm{ng} / \mathrm{ml}$.

Dissociated cell culture and plasmid transfection. For dissociated cell culture of the thalamus, blocks of the dorsal thalamus were dissected from E15 rat embryos and minced thoroughly. The tissues were washed extensively with PBS and incubated in Hanks' Balanced Salt Solutions (-) containing $0.125 \%$ trypsin. After trituration, dissociated thalamic cells were transfected with plasmids using Lipofectamine 2000 (Invitrogen) as follows. Dissociated cells $\left(1 \times 10^{5}\right)$ were suspended in $25 \mu \mathrm{l}$ of Opti-MEM (Invitrogen) containing DNA-Lipofectamine 2000 complexes and placed on a poly-L-ornithine-coated dish (four-well plate; Nalge Nunc). The dissociated neurons in transfection medium were then placed in a $\mathrm{CO}_{2}$ incubator. After $1 \mathrm{~h}$, the medium was replaced with culture medium (DMEM/F12; catalog no. 12500-062; Invitrogen) containing 5\% FBS (Hyclone) and $1 \times$ B-27 supplement (catalog no. 17504044; Invitrogen). Cells were cultured in humidified air and $5 \% \mathrm{CO}_{2}$ for 8 to 10 days.

For dissociated cell culture of the cortex, cortical hemispheres were dissected from E18 rat embryos and dissociated cells were prepared as described above. The cells were aliquoted and stored in liquid nitrogen. After thawing, these were seeded on $0.1 \mathrm{mg} / \mathrm{ml}$ poly-L-ornithine-coated plates at a density of $5000 \mathrm{cells} / \mathrm{cm}^{2}$ (24-well plate; Corning) and cultured in DMEM/F12 containing 5\% FBS and $1 \times$ B-27 supplement. Cells were cultured in humidified air and $5 \% \mathrm{CO}_{2}$ for 7 days.

Antibody-blocking experiment. Dissociated thalamic and cortical cells were prepared from E15 and E18 rats, respectively, as described above. Cortical cells were seeded on $0.1 \mathrm{mg} / \mathrm{ml}$ poly-L-ornithine-coated plates at a density of 5000 cells $/ \mathrm{cm}^{2}$ (48-well plate; Iwaki) in DMEM/F12 containing $5 \%$ FBS and $1 \times$ B-27 supplement. After attached to the bottom, cortical cells were incubated for $45 \mathrm{~min}$ in a serum-free medium containing $10 \mu \mathrm{M}$ CellTracker Dye (catalog no. C7025, Invitrogen). The medium was replaced with a fresh medium. Then, dissociated thalamic cells were added at a density of 10,000 cells $/ \mathrm{cm}^{2}$. After $24 \mathrm{~h}$ culturing, the culture medium was replaced with the medium containing either a mixture of rabbit anti-NRN1 (2 $\mu \mathrm{g} / \mathrm{ml}$; catalog no. sc-25651; Santa Cruz Biotechnology) and goat anti-VGF ( $2 \mu \mathrm{g} / \mathrm{ml}$; catalog no. sc-10381; Santa Cruz Biotechnology) antibodies or a mixture of normal rabbit IgG $(2 \mu \mathrm{g} / \mathrm{ml}$; catalog no. 2729, Cell Signaling Technology) and normal goat IgG (2 $\mu \mathrm{g} / \mathrm{ml}$; catalog no. sc-2028; Santa Cruz Biotechnology). Preservatives had been removed from these antibody solutions using a gel filtration column (HiTrap Desalting or PD-10 columns; GE Healthcare Life Sciences). The cultures were maintained in humidified air and $5 \% \mathrm{CO}_{2}$ for 7 days.

In utero electroporation. In utero electroporation was performed as described previously (Saito and Nakatsuji, 2001; Tabata and Nakajima, 2001) with slight modifications. Timed pregnant ICR mice of E13.5 were deeply anesthetized with Nembutal (pentobarbital, $50 \mathrm{mg} / \mathrm{kg}$ ). After the abdomen had been cleaned with $70 \%$ ethanol, a $3 \mathrm{~cm}$ midline laparotomy was performed, and the uterus was exposed. For DNA microinjection, plasmid DNA purified with the PureLink HiPure Plasmid Maxiprep Kit (Invitrogen) was dissolved in PBS. Fast Green solution (0.1\%) was added to the plasmid solution in a ratio of 1:20 to monitor the injection. Approximately $1-2 \mu \mathrm{l}$ of the plasmid solution was injected into the lateral ventricle with a glass micropipette that was connected to an injector (catalog no. IM-30, Narishige).

The embryos in the uterus were placed in a tweezers-type electrode that has disc-type electrodes of $5 \mathrm{~mm}$ diameter at the tip (catalog no. CUY650-5, Nepa Gene). Electronic pulses (30 V, $50 \mathrm{~ms}$ ) were delivered five times at intervals of $100 \mathrm{~ms}$ with an electroporator (catalog no. CUY21, Bex), after which the uterine horns were placed back into the abdominal cavity. The abdominal wall and skin were sewed up with surgical sutures, and the embryos were allowed to continue development until their brains were used for organotypic culture. To sparsely label a small number of cortical neurons so that individual neuronal morphology could be observed, a strategy based on the Cre/loxP system was used (Dhande et al., 2011). A mixture of $3 \mu \mathrm{g} / \mu \mathrm{l}$ pCAG-loxp-Neo-Stop-loxp-
EYFP (pCALNL-EYFP; where EYFP is enhanced yellow fluorescent protein) and 0.25-2 ng/ $\mu$ l pCAG-Cre plasmids (Matsuda and Cepko, 2007) was electroporated. The enhanced green fluorescent protein (EGFP) coding sequence of pCALNL-EGFP (a generous gift from Dr. Ed Ruthazer, McGill University, Montreal, Canada) was replaced by the EYFP coding sequence to yield pCALNL-EYFP.

Organotypic slice culture. Organotypic slice cultures of the cortex were prepared as described previously (Yamamoto et al., 1989, 1992). After electroporation, coronal slices containing EYFP-positive cells were dissected from $\mathrm{P} 0-1$ mice under a fluorescence microscope (catalog no. MZ FLIII, Leica). The slices were placed on a collagen-coated membrane insertion (Millicell-CM; catalog no. PICMORG50; Millipore) and cultured with DMEM/F12 (Invitrogen) containing 5\% FBS and 10\% N2 supplement. The cultures were maintained for 7 days in humidified air and $5 \% \mathrm{CO}_{2}$. The medium was exchanged with FBS-free DMEM/F12 containing $10 \% \mathrm{~N} 2$ supplement after several days in vitro (DIV).

Time-lapse study. To examine whether the cell fate of cortical neurons is affected by protein application, time-lapse imaging of slices containing EYFP-labeled neurons was performed. Photographs $(1380 \times 1380 \mu \mathrm{m})$ were taken of 1 DIV slices by confocal microscopy (Nikon, Digital Eclipse C1) with a $10 \times$ objective lens. A total of 7-13 optical sections were sampled at $7 \mu \mathrm{m}$ step size. Each observation was performed for $\sim 10 \mathrm{~min}$ at room temperature, and cultures were then returned to the incubator. Cells that showed unipolar morphology with a typical leading process were termed unipolar cells, whereas those having a round-shaped cell body and several short neurites were termed multipolar cells. Cells that showed no clear neurites were excluded from the analysis because their morphology could not be categorized. After 7 days in culture, the slices were fixed and immunostaining with anti-GFP antibody was performed to visualize the detailed morphology of the same labeled cells (see below, Immunohistochemistry). Individual cells were identified based on their position in a slice, labeling intensity, and geometric correlation with surrounding labeled cells. Cells that exhibited multipolar morphology without an apical dendrite were termed stellate cells, while those with an apical dendrite were termed pyramidal cells. The other cells, which could not be categorized into either of these two types because of their intermediate morphology between the two types, were termed intermediate cells. Cell types were compared between 1 and 7 DIV for each neurons.

Immunocytochemistry. Cultured dissociated cells were fixed in 4\% PFA in $0.1 \mathrm{M} \mathrm{PB}$ and $0.15 \mathrm{M} \mathrm{NaCl}$ for $30 \mathrm{~min}$ at RT. Fixed cultures were washed three times with PBS and incubated with PBS containing 2\% normal goat/donkey serum and $0.1 \%$ Triton X-100 (blocking buffer) for $30 \mathrm{~min}$ at RT. For thalamic cells transfected with candidate genes, cultures were incubated with anti-FLAG antibody (1:1000) or anti-human Fc antibody (1:800) diluted with blocking buffer overnight at $4^{\circ} \mathrm{C}$. After three washes, the cultures were incubated with Alexa Fluor 488conjugated goat anti-mouse IgG (1:500; catalog no. A11029, Invitrogen) or Alexa Fluor 488-conjugated donkey anti-goat $\operatorname{IgG}$ (1:500; catalog no. 705-485-003; Jackson ImmunoResearch Laboratories) for $2 \mathrm{~h}$ at RT. After three washes, images were obtained with a fluorescence microscope IX71 (Olympus Optical).

For cortical dissociated cells, cultures were incubated with antiacetylated tubulin (AcTub) antibody (1:7500; catalog T6793, SigmaAldrich). The signal was visualized with Alexa Fluor 488-conjugated anti-mouse IgG (1:500) or Cy3-conjugated donkey anti-mouse IgG (1: 500; catalog no. AP192C; Millipore Bioscience Research Reagents ). To distinguish dendrites from axons, immunocytochemistry with rabbit anti-microtubule associated protein 2 (MAP2) (1:1000; catalog no. AB5622; Millipore Bioscience Research Reagents) was performed, and the signal was visualized with Cy3-conjugated donkey anti-rabbit IgG (1:500; catalog no. AP182C, Millipore Bioscience Research Reagents ). To detect apoptotic cells, the cultures were stained with rabbit anticleaved caspase- 3 antibody (1:500; catalog no. 9661, Cell Signaling Technology) followed by incubation with $\mathrm{Cy} 3$-conjugated donkey anti-rabbit $\operatorname{IgG}(1: 500)$. The cells were finally counterstained with $4^{\prime}$,6-diamidino2-phenylindole (DAPI) to visualize their nuclei.

Immunohistochemistry. For immunohistochemistry of NRN1 and VGF, P7 mouse and rat brains were fixed with $4 \%$ PFA in PB for $1 \mathrm{~h}$ at $4^{\circ} \mathrm{C}$ and incubated in sucrose-containing PBS ( $\mathrm{pH} 7.4$ ). After the brains were 
frozen with liquid nitrogen, coronal sections $(50 \mu \mathrm{m})$ were cut with a cryostat. For NRN1 staining, sections were treated with antigen retrieval solution (HistoVT One, Nacalai Tesque) for $20 \mathrm{~min}$ at $70^{\circ} \mathrm{C}$. After incubation with PBS containing 5\% normal goat/donkey serum and $0.1 \%$ Triton X-100 (blocking buffer) for $1 \mathrm{~h}$ at RT, the sections were incubated for $48 \mathrm{~h}$ at $4^{\circ} \mathrm{C}$ with the rabbit anti-NRN1 (1:50) or the goat anti-VGF $(1: 50)$ in the blocking buffer. After three washes, the sections were incubated with Cy3-conjugated donkey anti-rabbit secondary antibody (1: $500)$ or Cy3-conugated donkey anti-goat secondary antibody (1:500; catalog no. 705-165-147; Jackson ImmunoResearch Laboratories).

Immunostaining with anti-GFP was performed to enhance the fluorescence of electroporated neurons in cortical slice cultures. Cultures were fixed in $4 \%$ PFA in $0.1 \mathrm{M} \mathrm{PB}$ and $0.15 \mathrm{M} \mathrm{NaCl}$ for $2-3 \mathrm{~h}$ at RT, washed five times in PBS, and then incubated in PBS containing 5\% normal goat serum and $0.3 \%$ Triton X-100 (blocking buffer) for $1 \mathrm{~h}$ at RT. Cultured slices on a membrane were cut out from the insertion and incubated with anti-GFP antibody (1:2000; catalog no. GF090R, Nacalai Tesque) in blocking buffer overnight at $4^{\circ} \mathrm{C}$. After five washes in PBS containing $0.3 \%$ Triton X-100, the cultures were incubated with Alexa Fluor 488-conjugated anti-rat IgG (1:500; catalog no. A11006; Invitrogen) for $2 \mathrm{~h}$ at RT. After five washes, the slices were mounted on glass slides and encapsulated with coverslips.

For immunostaining of layer markers, the cultured cortical slices were fixed with $4 \%$ PFA for $3 \mathrm{~h}$ followed by incubation in 30\% sucrose in PBS. The slices were embedded on an agar block ( $4 \%$ agar in PBS) and cut into $20 \mu \mathrm{m}$ sections with a cryostat. After incubating in PBS containing 5\% normal goat serum and $0.1 \%$ Triton X-100 (blocking buffer) for $1 \mathrm{~h}$ at RT, the sections were incubated with rabbit anti-CUX1 (1:100; catalog no. sc-13024; Santa Cruz Biotechnology), rabbit anti-ROR $\beta$ (1:5000; catalog no. pAb-RORbHS-100; Diagenode) or rabbit anti-ER81 (a generous gift from Dr. Thomas Jessell, Columbia University, New York, NY) in blocking buffer overnight at $4^{\circ} \mathrm{C}$. After three washes in PBS containing $0.1 \%$ Triton $\mathrm{X}-100$, the cultures were incubated with Cy3-conjugated donkey anti-rabbit IgG (1:500) for $2 \mathrm{~h}$ at RT. After three washes, the slices were mounted on glass slides and encapsulated with coverslips. The cultures were imaged by confocal microscopy.

Quantifications. To analyze neurite morphology, four or five fields $(877 \times 660 \mu \mathrm{m})$ were photographed randomly from the culture dishes using a fluorescence microscope (IX71, Olympus) with a $10 \times$ objective lens. Neurites from anti-AcTub-positive cells that did not overlap with other cells were traced. Neurite length and number were measured using Object-Image 2.15 software and morphometry macros as described elsewhere (Maruyama et al., 2008). The average and SEM of the number of primary dendrites and the total length of dendrites were calculated for each experimental condition.

To quantify the density of cultured cortical cells, four or five fields $(2193 \times 1651 \mu \mathrm{m})$ were also photographed randomly from each culture dish with a $4 \times$ objective lens. Cells strongly stained with anti-AcTub antibody were counted as neurons. Cell density was calculated by dividing the cell number by the surface area. The data were obtained from two or three individual experiments. The average and SEM of the neuron density were calculated for each experimental condition.

To quantify dendritic morphology of cultured cortical neurons in organotypic slices, photographs $(690 \times 690 \mu \mathrm{m})$ of sparsely labeled neurons were taken from 7 DIV slices by confocal microscopy (Nikon) with a $20 \times$ objective lens after immunohistochemistry with anti-GFP antibody (see above, Immunohistochemistry). A total of 15-25 optical sections were sampled at $4 \mu \mathrm{m}$ step size. Clearly labeled neurons were randomly selected, and the length and number of dendrites were measured using Object-Image 2.15 software and morphometry macros as described above. The average and SEM of the number of primary dendrites and the total length of dendrites were calculated for each experimental condition. Statistical significance between groups was determined using Student's $t$ test.

Pyramidal morphology index. Pyramidal morphology index (PMI) was calculated according to the method as described elsewhere (Hand et al., 2005 ) with slight modification. Dendritic morphology of cultured cortical neurons at 14 DIV was visualized by immunostaining with antiMAP2 antibody. The width of dendrites and the number of dendrites emerging from the cell body were sampled using a sampling circle around a cell body using an ImageJ plugin, Oval Profile Plot. The coordinates of the pixel values along the sampling circle were then imported into Excel (Microsoft Office v. X). A macro in Excel was written to normalize pixel values and binarize them $(>20 \%$ of $\max =1)$ so that contiguous positive pixels were counted as one process. The sum of adjacent positive points was used to calculate the relative width of each process. For each cell the PMI was determined as the width of the thickest process divided by the total number of processes that crossed the sampling circle. To compare the PMI between control and treated groups, each PMI value was normalized with the average of control. The significance between groups was compared using Student's $t$ test.

\section{Results}

\section{Identification of thalamus-specific genes}

To identify thalamus-derived extrinsic factors that may affect cortical cell differentiation, we searched for genes that are expressed specifically in the thalamus but not in the cortex. For this, differential gene expression between the thalamus (the dorsal part of the LGN) and cortex (layer 1-5) was examined by microarray analysis using $\mathrm{P} 3$ rat brain (Fig. $1 A, B$ ), at which stage thalamic axons start to interact with cortical cells in layer 4 (Kageyama and Robertson, 1993; Catalano et al., 1996; Molnar et al., 1998). In addition, cortical neuron morphology begins to mature in terms of dendritic arborization and axonal projection from this period (Miller, 1986). A total of 137 transcripts ( $0.5 \%$ of the total number) showed significantly higher expression in the thalamus than in the cortex (Fig. 1C). To search more comprehensively for thalamus-specific genes, a subtraction cDNA library was constructed in which thalamic cDNAs were enriched by subtracting cortical cDNAs (Fig. $1 A$ ). PCR amplification of a constitutively expressed gene, Gapdh, demonstrated that the amount of Gapdh cDNA was reduced in subtracted cDNA population to a thousandth part of that in unsubtracted cDNAs, ensuring the efficiency of subtraction (Fig. 1D). A random sequence analysis of the subtraction library revealed the existence of 185 different genes in this library. Many of these genes overlapped with those identified by the microarray analysis, but a distinct set of genes were also obtained from the analysis. As a consequence, we obtained a total of 241 candidate thalamus-specific genes from both analyses.

A thalamic axon-derived influence is likely to be mediated by extracellular molecules, including secretory or membranebound proteins. Based on the public database and previous reports, 23 of 241 genes were found to encode these molecular species. In situ hybridization demonstrated that 10 of these genes were strongly expressed in the thalamus, and comprised of three groups (Table 1). The first group showed exclusive expression in the dLGN (Fig. 2A). The second exhibited strong expression in more than two sensory thalamic nuclei of dLGN, ventrobasal complex (VB) and medial geniculate (MG) nucleus (Fig. $2 B$ ). The third group was broadly expressed in the entire thalamus (Fig. 2C). Since sensory thalamic neurons send abundant axons to sensory cortical areas in which layer 4 develops with spiny stellate neurons, we focused on the second group. Consequently, NRN1, VGF, and WNT2B were chosen for thalamus-derived extrinsic factors.

\section{Accumulation of thalamus-specific proteins in axon terminals of thalamic neurons}

As thalamus-derived factors that affect cortical cell differentiation should be transported from cell bodies to axon terminals, transportation of the candidate proteins was tested in dissociated thalamic cells in vitro. To do this, expression plas- 
A
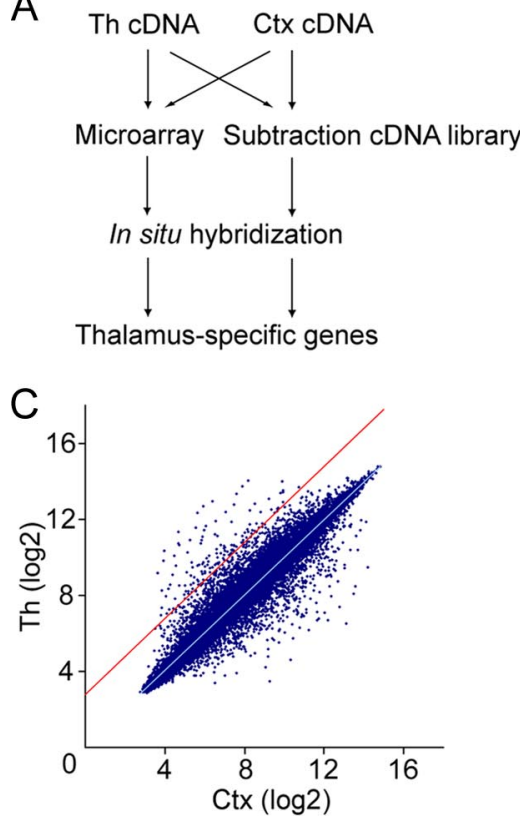

B

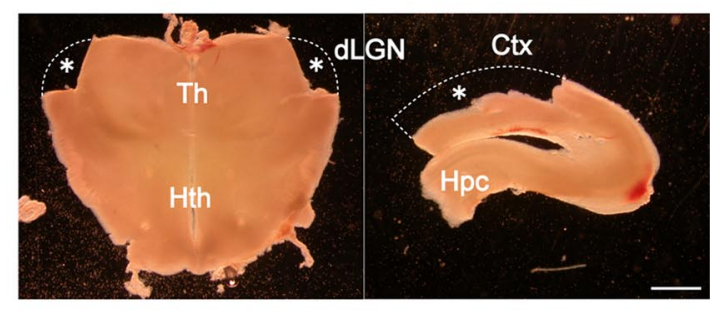

D

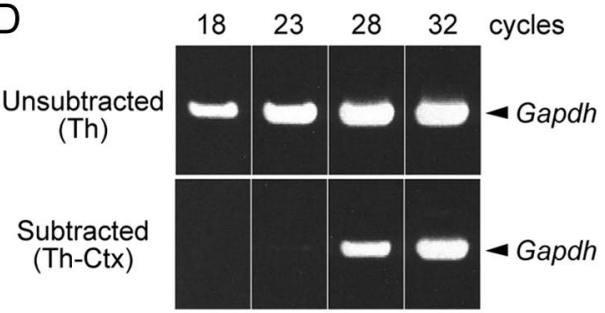

Figure 1. Thalamus-specific genes identified by microarray analysis and screening of a subtraction cDNA library. $\boldsymbol{A}$, Flow chart for the identification of thalamus-specific genes. $\boldsymbol{B}$, Dissection of a thalamic nucleus, the dLGN (left), and cortical plate (right) from P3 rat. Asterisks and dotted lines mark the positions of dissected tissues. $\boldsymbol{C}$, Comparison of gene expression in the thalamus and cortex using microarrays. The blue line represents the average distribution of signals, and the red line indicates sevenfold higher expression in the thalamus than in the cortex. $D$, Subtraction efficiency of the constructed subtraction cDNA library. PCR amplification of Gapdh shows a reduced amount of Gapdh cDNA in subtracted cDNAs (bottom panel) compared with unsubtracted cDNAs (top panel). Scale bar, 1 mm. Th, Thalamus; Ctx, cortex; Hth, hypothalamus; Hpc, hippocampus.

Table 1. List of thalamus-specific genes and their expression patterns

\begin{tabular}{|c|c|c|c|c|}
\hline $\begin{array}{l}\text { Expression } \\
\text { pattern }\end{array}$ & $\begin{array}{l}\text { Gene } \\
\text { symbol }\end{array}$ & Gene name & Category & Microarray \\
\hline $\mathrm{dLGN}$ & Tmem192 & Transmembrane protein 192 & Membrane protein & 66.5 \\
\hline Sensory Th & Nrn1 & Neuritin & Secretory protein & 54.2 \\
\hline Sensory Th & Vgf & VGF nerve growth factor inducible & Secretory protein & 56.9 \\
\hline Sensory Th & Wnt2b & $\begin{array}{l}\text { Wingless related MMTV integration } \\
\text { site } 2 b\end{array}$ & Secretory protein & 15.0 \\
\hline Entire Th & Agt & Angiotensinogen & Secretory protein & 11.4 \\
\hline Entire Th & Angpt2 & Angiopoietin 2 & Secretory protein & 9.0 \\
\hline Entire Th & Col25a1 & Collagen, type XXV, alpha 1 isoform 1 & Extracellular matrix & 15.3 \\
\hline Entire Th & Kitl & kit ligand & Secretory protein & 30.2 \\
\hline Entire Th & Ntng1 & Netrin G1 & Membrane-bound & 93.8 \\
\hline Entire Th & Ptprz1 & $\begin{array}{l}\text { Protein tyrosine phosphatase, } \\
\text { receptor-type, } \\
\text { Z polypeptide1, extracellular variant }\end{array}$ & Secretory protein & $\mathrm{NE}$ \\
\hline
\end{tabular}

Microarray displays the ratio of thalamic to cortical expression level. NE, Not examined.

mids encoding the thalamus-specific genes were cotransfected with DsRed plasmid into dissociated thalamic cells prepared from E15 rat. The subcellular distribution of the encoded proteins was examined after 10 days of culturing, which allows neurons to extend their neurites. NRN1 and VGF signals were present throughout cell bodies, dendrites, and axons (Fig. $3 A, B$ ), and particularly strong in axon terminals (Fig. $3 \mathrm{~A}^{\prime}, B^{\prime}$ ). In contrast, WNT2B was restricted to the proximal parts of neurites and cell bodies and was absent from axons (Fig. $3 C, C^{\prime}$ ). Thus, NRN1 and VGF were finally identified as molecules that are strongly expressed in developing sensory thalamic nuclei and accumulate in the thalamic axon terminals.

\section{Developmental expression patterns of $\mathrm{Nrn} 1$ and $V g f$}

The expression patterns of $\mathrm{Nrn} 1$ and $V g f$ during development were investigated in detail by in situ hybridization. Nrn1 showed strong expression in the thalamus at postnatal stages (Fig. 4A). At P3 and P7 it was strongly expressed in the dLGN, $\mathrm{VB}$, and MG, but not in the neocortex. Nrn1 was also expressed moderately in other thalamic nuclei including lateral posterior and posterior thalamic nucleus, whose neurons send axons to the secondary sensory area of the cortex (Hughes, 1977; Caviness and Frost, 1980). Nrn1 was already expressed in the thalamus at E18, when thalamic axons start to invade the cortical plate, and was continuously expressed in the thalamus until P14 (Fig. 4A). Vgf was also strongly expressed in dLGN, $\mathrm{VB}$, and MG at P3 and P7, and its expression was more tightly restricted to sensory thalamic nuclei than that of Nrn1 (Fig. $4 B) . V g f$ was highly expressed in the dLGN at E18, P0, and P14. These results indicate that Nrn1 and $V g f$ are strongly expressed in sensory thalamic nuclei at those developmental stages when thalamocortical axons interact with cortical neurons.

Endogenous NRN1 and VGF are localized in thalamocortical axon terminals in cortical layer 4

Expression of endogenous NRN1 and VGF proteins were examined in the developing rodent brains with anti-NRN1 and antiVGF antibodies. NRN1 immunopositivity was found in the VB, where its mRNA was strongly expressed, in P7 mouse brain (Fig. $5 A, B)$. NRN1 signal was also found in layer 4 of the somatosensory cortex despite the lack of mRNA expression (Figs. 4A, $5 C, D)$. VGF immunoreactivity was found in the dLGN as well as the VB (Fig. $5 E, F$ ). Correspondingly, VGF signal was present in layer 4 of visual and somatosensory cortices, where its mRNA was absent (Figs. $4 B, 5 G, H$ ). In addition, VGF signal was also observed in the reticular nucleus and the white matter, which contain thalamic fibers (Fig. 5E-H). A similar expression pattern of VGF was observed in $\mathrm{P} 7$ rat brain (Fig. 5I-L). These results indicate that NRN1 and VGF, which are synthesized by thalamic 


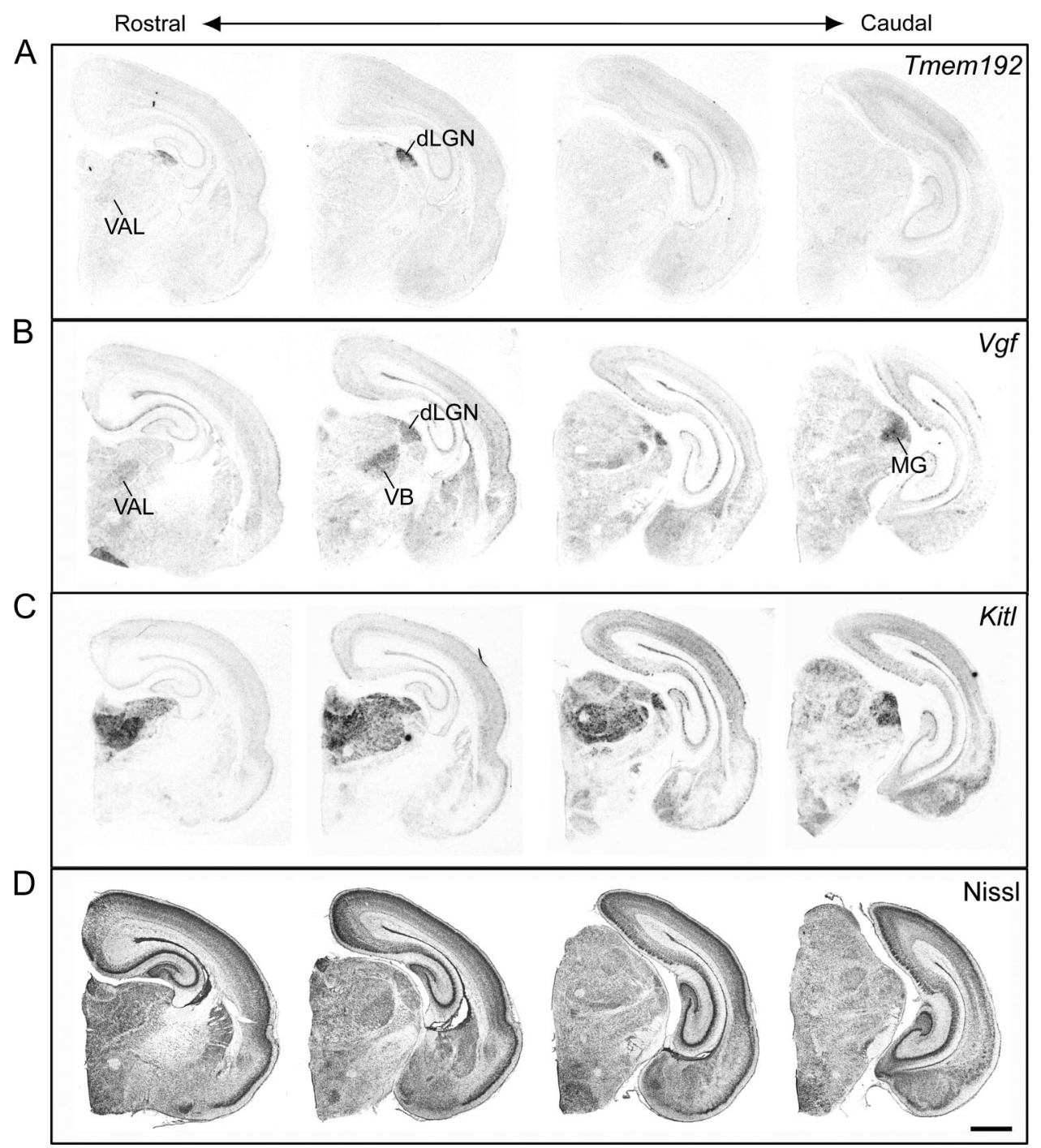

Figure 2. The thalamus-specific genes showed three different expression patterns. $\boldsymbol{A}$, In situ hybridization shows dLGN-specific expression of $T$ Tmem 192. B, Expression of $V g f$ is strong in sensory thalamic nuclei including the dLGN, VB, and MG. C, Kitl is expressed in the entire thalamus. D, Nissl staining of comparable sections. Scale bar, $1 \mathrm{~mm}$.

neurons, are transported to the developing cortex through thalamic axons.

\section{NRN1 and VGF promote dendritic growth of cortical neurons} First, the roles of NRN1 and VGF on cortical neurons were investigated using dissociated cell culture. Dissociated cells were prepared from E18 rat cortex, which contains all layer neurons, plated at a low density $\left(5000 \mathrm{cells} / \mathrm{cm}^{2}\right)$, and exposed to either protein. Since NRN1 and VGF are expressed in the thalamus but not in the cortex and are thus likely to reach cortical neurons via the extracellular environment, we reasoned that exogenous application of these proteins would mimic their effects on cortical cell development.

We examined whether neurite growth was affected by the application of the two candidate proteins. To distinguish axons and dendrites, immunocytochemistry with antibodies against MAP2 and AcTub was performed. AcTub signal was detected in all neurites, while the longest process was devoid of MAP2 signal (Fig. 6A-C, $A^{\prime}-C^{\prime}$ ), as reported previously (Caceres et al., 1984). Based on this criterion, dendritic morphology was analyzed separately from axonal morphology.
Several dendrites were observed to extend from cell bodies at $7 \mathrm{DIV}$ in the normal culture medium (Fig. 6D). A greater number of primary dendrites emerged in the presence of NRN1 (Fig. 6E), and quantitative analysis revealed that NRN1 application increased the number in a dose-dependent manner $(5.66 \pm 0.23$ for the control; $7.23 \pm 0.29, P<0.01$ for 20 $\mathrm{ng} / \mathrm{ml} ; 8.06 \pm 0.34, P<0.01$ for $200 \mathrm{ng} / \mathrm{ml} ; 6.98 \pm 0.27, P<$ 0.01 for $2000 \mathrm{ng} / \mathrm{ml} ; n=90$ cells for each concentration) (Fig. $6 G)$. The total length of dendrites also increased in response to NRN1 (145.7 $\pm 7.52 \mu \mathrm{m}$ for the control; $188.8 \pm 8.73 \mu \mathrm{m}, P<$ 0.01 for $20 \mathrm{ng} / \mathrm{ml} ; 201.2 \pm 9.00 \mu \mathrm{m}, P<0.01$ for $200 \mathrm{ng} / \mathrm{ml}$; $177.9 \pm 9.03 \mu \mathrm{m}, P<0.01$ for $2000 \mathrm{ng} / \mathrm{ml} ; n=90$ cells for each concentration) (Fig. $6 H$ ). Similarly, VGF application significantly increased the number of primary dendrites $(5.56 \pm$ $0.28, n=50$ cells for the control; $6.53 \pm 0.27, n=45$ cells, $P<$ 0.05 for $30 \mathrm{ng} / \mathrm{ml} ; 6.96 \pm 0.25, n=54$ cells, $P<0.01$ for 300 $\mathrm{ng} / \mathrm{ml} ; 6.2 \pm 0.57, n=10$ cells, $P>0.05$ for $3000 \mathrm{ng} / \mathrm{ml}$ ) (Fig. $6 D, F, I)$, and the total length of dendrites $(131.1 \pm 8.44 \mu \mathrm{m}$, $n=50$ cells for the control; $181.0 \pm 10.8 \mu \mathrm{m}, n=45$ cells, $P<$ 0.01 for $30 \mathrm{ng} / \mathrm{ml} ; 203.9 \pm 12.0 \mu \mathrm{m}, n=54$ cells, $P<0.01$ for $300 \mathrm{ng} / \mathrm{ml} ; 141.2 \pm 15.0 \mu \mathrm{m}, n=10$ cells, $P>0.05$ for 3000 
$\mathrm{ng} / \mathrm{ml}$ ) (Fig. 6J). These results indicate that dendritic growth of cortical neurons is promoted by NRN1 and VGF.

\section{Endogenous NRN1 and VGF regulate} dendritic growth of cortical neurons Whether NRN1 and VGF secreted from thalamic neurons promote dendritic growth of cortical neurons was studied by blocking or absorbing endogenous NRN1 and VGF with their antibodies. For this, cortical neurons labeled with a fluorescent dye were cocultured with thalamic neurons in the presence of antibodies against NRN1 and VGF. Then, dendritic growth of cortical neurons was analyzed at 7 DIV (Fig. 7A-F). As a result, the application of these antibodies significantly decreased the number of primary dendrites $(6.54 \pm 0.15, n=116$ cells for the control IgG; $5.20 \pm 0.18, n=120$ cells, $P<0.01$ for anti-NRN1 and VGF) and total dendritic length $(200.1 \pm 9.5 \mu \mathrm{m}$, $n=116$ cells for the control IgG; $140.2 \pm$ $6.7 \mu \mathrm{m}, n=120$ cells, $P<0.01$ for antiNRN1 and VGF) compared with the control IgG application (Fig. 7G,H). This result suggests that NRN1 and VGF secreted from thalamic neurons can promote dendritic growth of cortical neurons.

\section{The function of NRN1 and VGF in dendritic growth is specific to stellate neurons in layer 4 \\ We further examined which cell type is af-} fected in dendritic growth. For this, organotypic slice culture was used, since laminar structure and neuronal cell type are well preserved in this system (Yamamoto et al., 1992); that is, more intact cellular morphology can be analyzed with the exclusion of thalamic influences. First, cortical neurons that are destined to become layer 4 and layer 5 were transfected with the EYFP plasmid by in utero electroporation of E13.5 and E12.5 mice, respectively (Ajioka and Nakajima, 2005). Sparse labeling with a Cre/loxp sys-

tem was used for morphological analysis of individual neurons (see Materials and Methods). Cortical slices were then dissected from the parietal and occipital regions of newborn mouse cortices and cultured in the presence or absence of either NRN1 $(800 \mathrm{ng} / \mathrm{ml})$ or VGF (1200 ng/ml) for 7 days (Fig. $8 A$ ).

Most of the cells electroporated at E13.5 showed multipolar cell type and resembled spiny stellate neurons in vivo (Fig. $8 \mathrm{~B}$ ), although a few exhibited pyramidal cell morphology. On the other hand, electroporation at E12.5 predominantly labeled pyramidal cells with apical dendrites (Fig. 8C). To verify cell type, we examined layer marker expression in EYFP-labeled cells using anti-CUX1 for layers 2-4 (Nieto et al., 2004), anti-ROR $\beta$ for layer 4 (Schaeren-Wiemers et al., 1997), and anti-ER81 for layer 5 (Hevner et al., 2003; Yoneshima et al., 2006). The EYFP-labeled cells (electroporated at E13.5), identified morphologically as stellate cells, were positive for CUX1 and ROR $\beta$ and were negative for ER8 1 at 7 DIV (15/15 cell for CUX1; 29/33 cells for ROR $\beta$; 0/29 cells for ER81) (Fig. 8D, Table 2). In contrast, E12.5 electroporated cells identified as pyramidal cells were mostly negative for CUX1 and ROR $\beta$ and were partially positive for ER81, which are expressed in a subpopulation of layer 5 pyramidal neurons (Yoneshima et al., 2006) (1/19 cells for CUX1; 0/7 cells for ROR $\beta$; 7/26 cells for ER81) (Fig. 8D, Table 2). Thus, our morphological classification is consistent with the expression of the layer markers.

We found that NRN1 and VGF application promoted dendritic growth of stellate cells (Fig. $8 E-G$ ). The number of primary dendrites was increased significantly by either NRN1 or VGF application $(5.07 \pm 0.32, n=27$ cells for the control; $7.06 \pm 0.41, n=17$ cells, $P<0.01$ for NRN1; $6.87 \pm 0.31, n=$ 31 cells, $P<0.01$ for VGF) (Fig. $8 K$ ). Likewise, the total length 


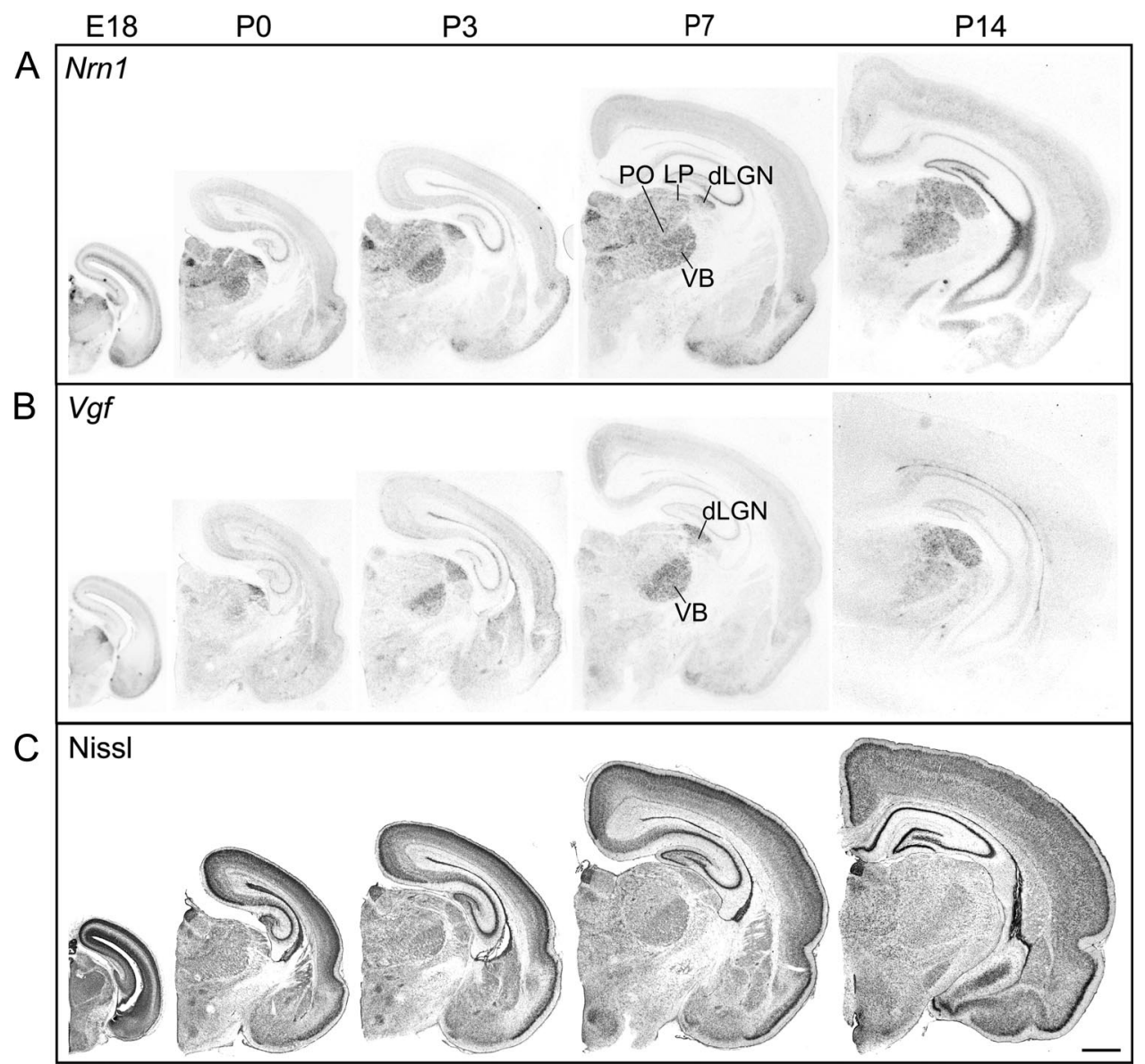

Figure 4. Nrn1 and Vgf are expressed in the thalamus during development. A, In situ hybridization revealed that Nrn1 is strongly expressed in sensory thalamic nuclei, dLGN, VB, and MG and moderately expressed in other thalamic nuclei from E18 to P14. B, Vgf shows more specific expression in sensory thalamic nuclei from E18 to P14. C, Nissl staining of comparable sections. Scale bar, $1 \mathrm{~mm}$.
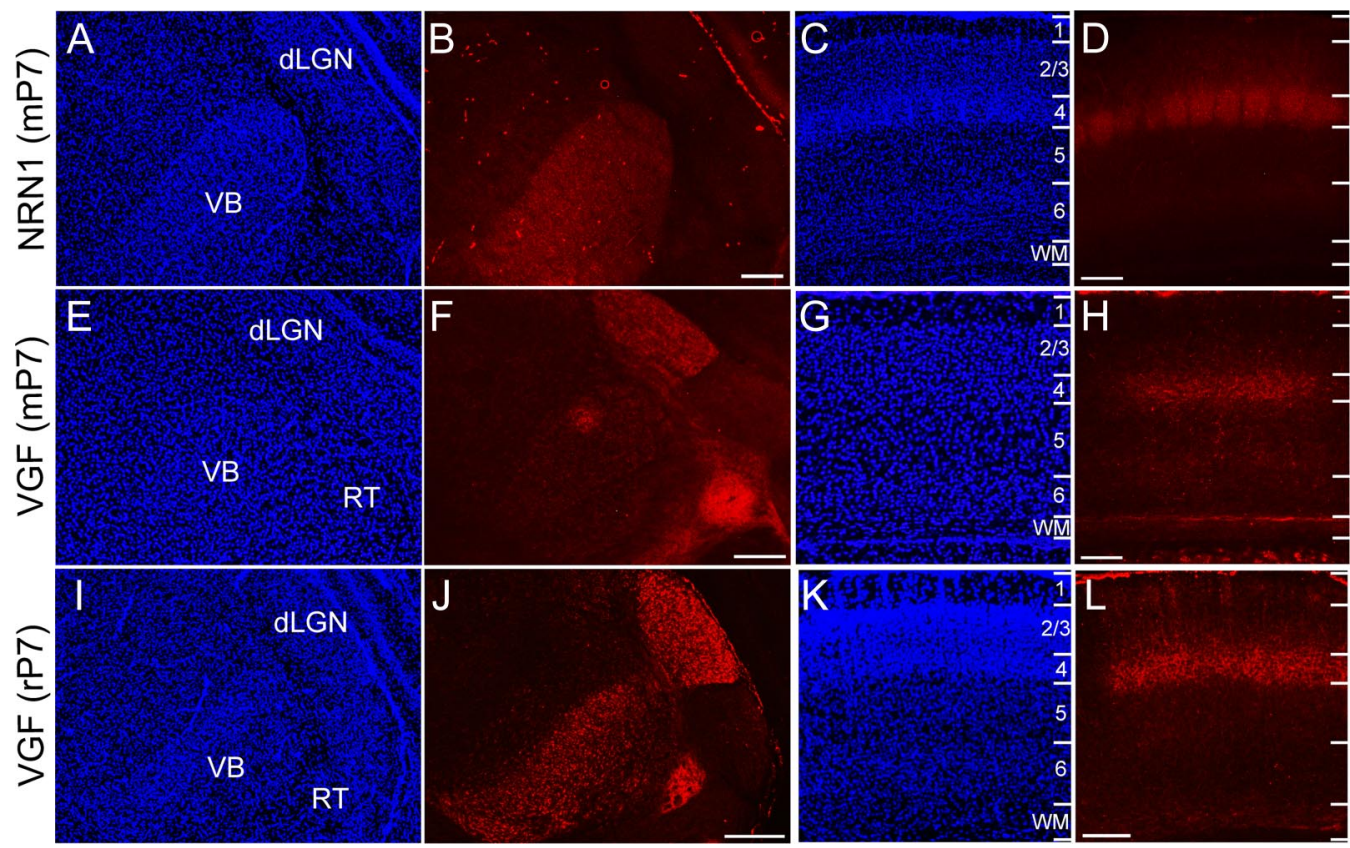

Figure 5. NRN1 and VGF are accumulated in thalamic axon terminals in cortical layer $4 . \boldsymbol{A}-\boldsymbol{D}$, Immunopositivity for NRN1 in the VB nucleus in the thalamus $(\boldsymbol{B})$ and in barrels in layer 4 of the primary somatosensory area in P7 mouse (D). $\boldsymbol{E}-\boldsymbol{L}, \mathrm{VGF}$ distribution in P7 mouse $(\boldsymbol{E}-\boldsymbol{H})$ and P7 rat $(\boldsymbol{I}-\boldsymbol{L})$ brains. Immunostaining signal ofVGF in the dLGN, VB, and reticular nuclei (RT) in the thalamus $(\boldsymbol{F}, \boldsymbol{J})$ and in layer 4 of the primary visual area $(\boldsymbol{H}, \boldsymbol{L})$. Nuclear DAPI staining is shown $(\boldsymbol{A}, \boldsymbol{C}, \boldsymbol{E}, \boldsymbol{G}, \boldsymbol{I}, \boldsymbol{K})$. Scale bars, $\boldsymbol{A}-\boldsymbol{F}, 100 \mu \mathrm{m} ; \boldsymbol{G}, \boldsymbol{H}, 50 \mu \mathrm{m} ; \boldsymbol{I}, \boldsymbol{J}, 500 \mu \mathrm{m} ; \boldsymbol{K}, \boldsymbol{L}, 200 \mu \mathrm{m}$. 

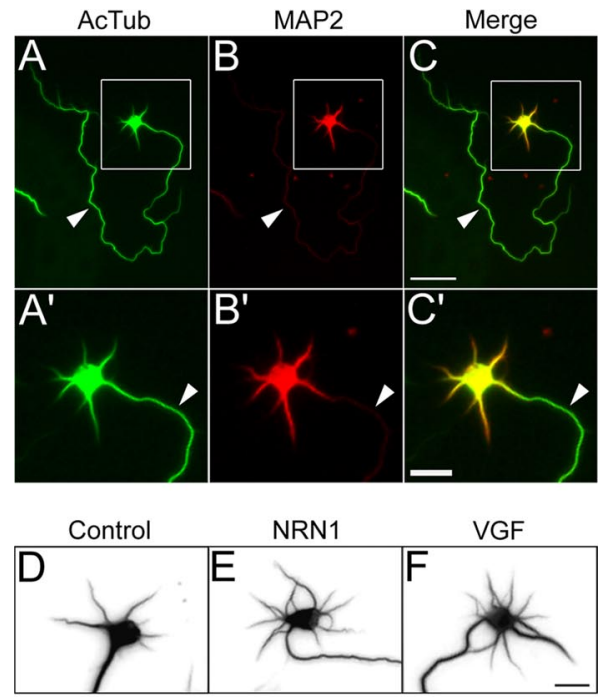
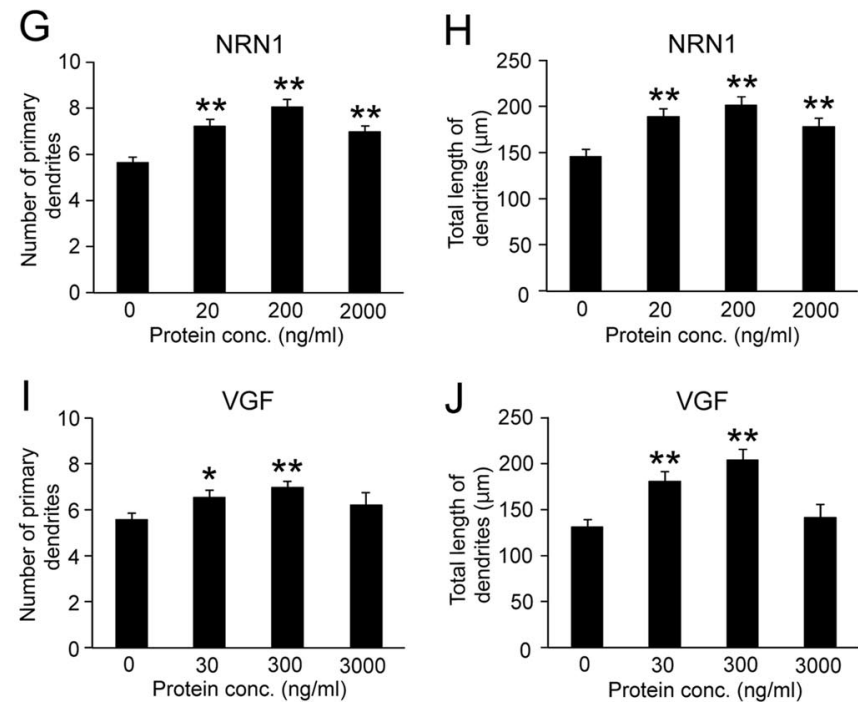

Figure 6. NRN1 and VGF promote dendritic growth of cortical neurons. $\left(\boldsymbol{A}-\boldsymbol{C}, \boldsymbol{A}^{\prime}-\boldsymbol{C}^{\prime}\right)$ Discrimination of axons and dendrites in the cortical cell culture. Cortical neurons were stained with antibodies against AcTub $\left(\boldsymbol{A}, \boldsymbol{A}^{\prime}\right)$ and MAP2 $\left(\boldsymbol{B}, \boldsymbol{B}^{\prime}\right)$ after 7 days in culture. The longest neurite is AcTub-positive but MAP2 negative (arrowheads). The other neurites are double-positive. $\boldsymbol{D}-\boldsymbol{F}$, Purified candidate proteins were added to the culture medium of cortical cells dissected from E18 rat. $\mathbf{G}-J$, Quantitative analysis of dendritic growth in the presence of NRN1 $(\boldsymbol{G}, \boldsymbol{H})$ or VGF $(\boldsymbol{I}, \boldsymbol{J})$. The number of primary dendrites $(\boldsymbol{G}, \boldsymbol{I})$ and the total length of dendrites $(\boldsymbol{H}, \boldsymbol{J})$ were measured after incubation with different concentrations (conc.) of these proteins. Scale bars: $\boldsymbol{A}-\boldsymbol{C}, 50 \mu \mathrm{m} ; \boldsymbol{A}^{\prime}-\boldsymbol{C}^{\prime}$ and $\boldsymbol{D}-\boldsymbol{F}, 20 \mu \mathrm{m} .{ }^{*} P<$ $0.05,{ }^{* *} p<0.01, t$ test.
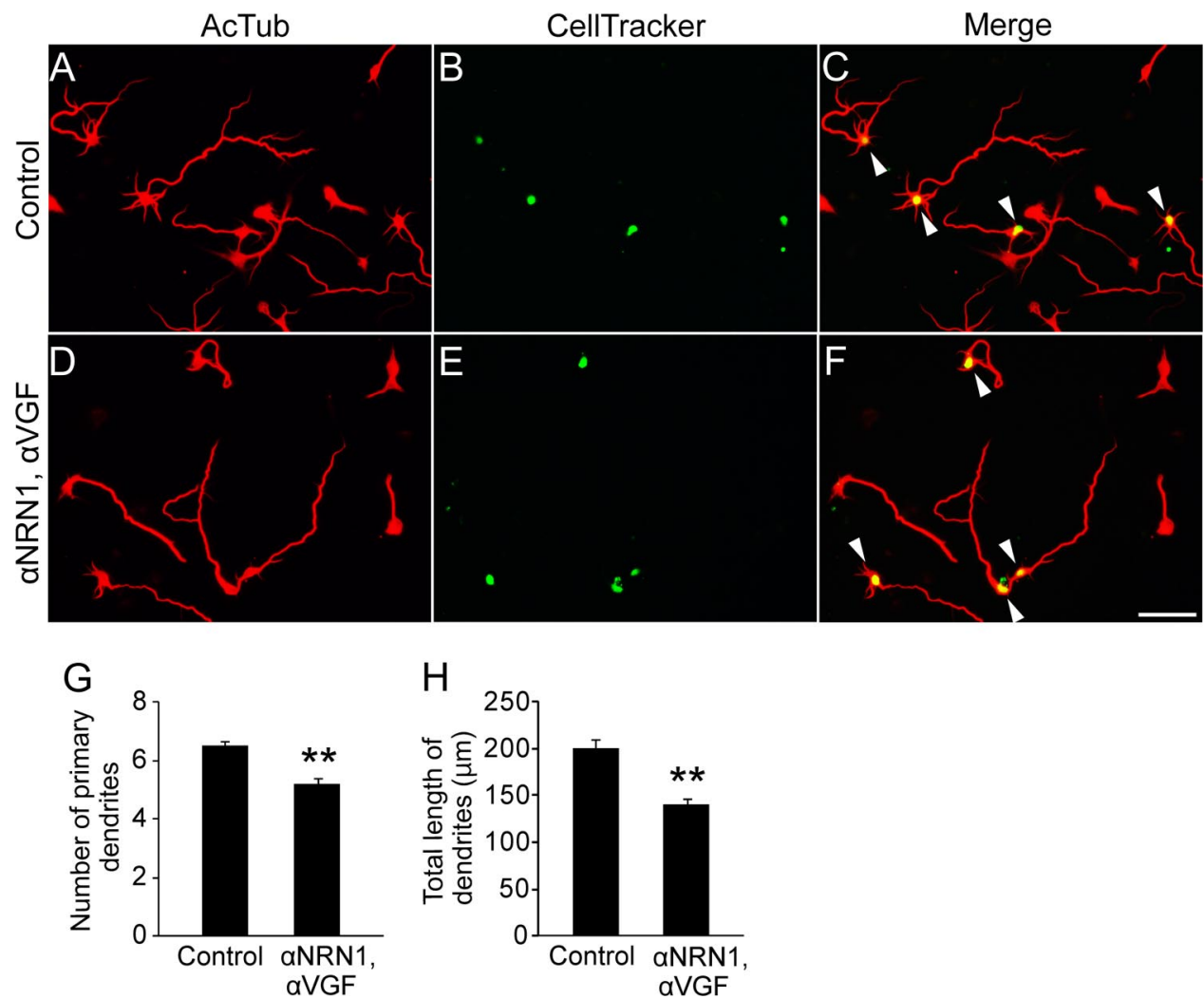

Figure 7. Block of endogenous NRN1 and VGF reduced dendritic growth of cortical neurons. $\boldsymbol{A}-\boldsymbol{F}$, Cortical neurons labeled with CellTracker ( $\boldsymbol{C}, \boldsymbol{F}$, arrowheads) were cocultured with unlabeled thalamic neurons in the presence of control $\operatorname{lgG}(\boldsymbol{A}-\boldsymbol{C})$ or anti-NRN1 and anti-VGF antibodies $(\boldsymbol{D}-\boldsymbol{F}) . \mathbf{G}, \boldsymbol{H}$, Quantitative analysis of the number of dendrites $(\boldsymbol{G})$ and the total length of dendrites $(\boldsymbol{H})$. Scale bar, $100 \mu \mathrm{m} .{ }^{* *} p<0.01, t$ test.

of dendrites increased in response to NRN1 or VGF $(1067 \pm$ $101 \mu \mathrm{m}, n=27$ cells for the control; $1499 \pm 112, n=17$ cells, $P<0.01$ for NRN1; $1336 \pm 101, n=31$ cells, $P<0.05$ for VGF) (Fig. $8 L$ ).

In contrast, dendritic growth of layer 5 pyramidal cells was not promoted by either NRN1 or VGF application (Fig. $8 \mathrm{H}-\mathrm{J}$ ). The number of primary dendrites $(5.28 \pm 0.27, n=25$ cells for the control; $4.58 \pm 0.25, n=31$ cells, $P<0.05$ for NRN1; $5.57 \pm$ $0.38, n=21$ cells, $p>0.05$ for VGF) and the total length of dendrites (1360 $\pm 137 \mu \mathrm{m}, n=25$ cells for control; $1409 \pm 132$, $n=31$ cells, $p>0.05$ for NRN1; $1427 \pm 73, n=21$ cells, $p>0.05$ for VGF) did not increase following protein application (Fig. 
A

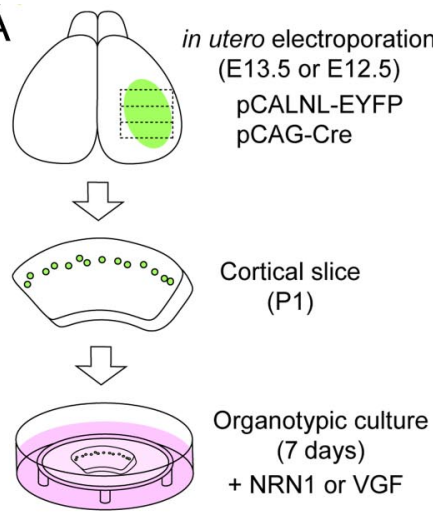

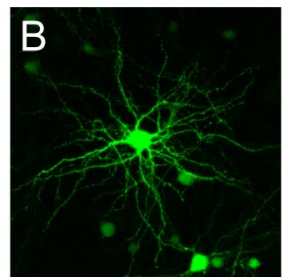

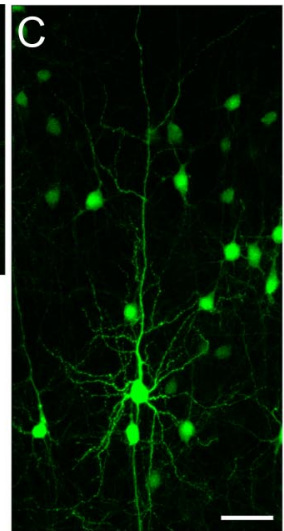

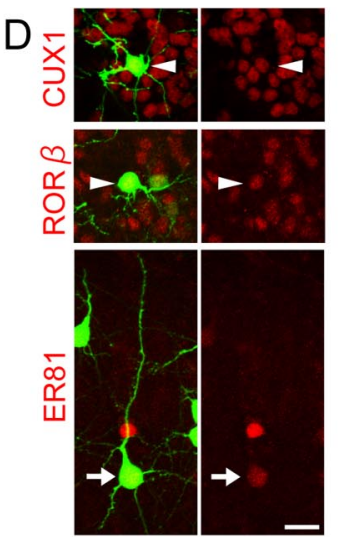
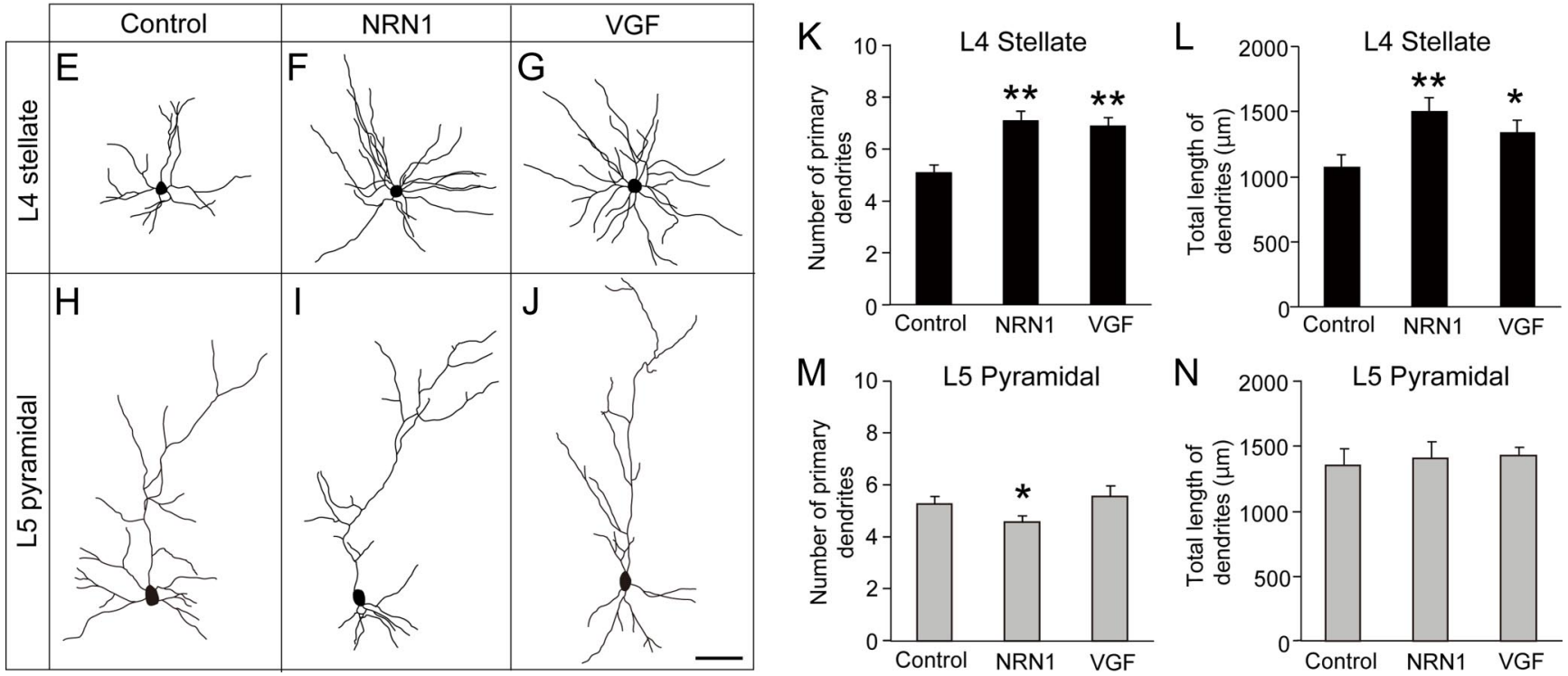

Figure 8. NRN1 and VGF specifically affect dendritic growth of stellate neurons. $\boldsymbol{A}$, Schematic representation of experimental design for cortical slice culture. $\boldsymbol{B}$, $\boldsymbol{C}$, Morphology of an EYFP-labeled stellate $(\boldsymbol{B})$ and pyramidal cell (C).D, Expression of layer markers in particular cell types. CUX1 and ROR $\beta$ are expressed in layer 4 stellate cells (arrowheads), whereas ER81 is expressed in a layer 5 pyramidal cell (arrow). $\boldsymbol{E}-\boldsymbol{J}$, Typical examples of individual layer 4 stellate cells $(\boldsymbol{E}-\boldsymbol{G})$ and layer 5 pyramidal cells $(\boldsymbol{H}-\boldsymbol{J})$ at 7 DIV. $\boldsymbol{K}, \boldsymbol{L}, \mathbf{Q}$ Quantitative analysis of the number and the total length of primary dendrites of sampled stellate cells was performed after culturing in the presence and absence of the thalamus-specific factors. $\boldsymbol{M}, \boldsymbol{N}$, The same quantitative analysis for pyramidal cells. Scale bars: $\boldsymbol{B}, \boldsymbol{C}, \boldsymbol{E}-\boldsymbol{J}, 50 \mu \mathrm{m} ; \boldsymbol{D}, 20 \mu \mathrm{m} .{ }^{*} P<0.05,{ }^{* *} P<0.01, t$ test.

Table 2. Expression of layer markers in each cell type at 1 and 7 DIV

\begin{tabular}{lllll}
\hline Layer marker & 1 DIV & 1 DIV & 7 DIV & 7 DIV \\
L4 Multipolar & L5 Unipolar & L4 Stellate & L5 Pyramidal \\
\hline CUX1 (L2-4) & $88.0 \%(22 / 25)$ & $4.2 \%(1 / 24)$ & $100 \%(15 / 15)$ & $5.3 \%(1 / 19)$ \\
ROR $\beta$ (L4) & ND & ND & $87.9 \%(29 / 33)$ & $0 \%(0 / 7)$ \\
ER81 (L5) & $3.3 \%(1 / 30)$ & $34.8 \%(16 / 46)$ & $0 \%(0 / 29)$ & $26.9 \%(7 / 26)$ \\
\hline
\end{tabular}

The percentages of CUX1-, ROR $\beta$-, and ER81-positive cells among multipolar and unipolar cells at 1 DIV and stellate- and pyramidal-shaped cells at 7 DIV are shown. The number of the marker-positive cells was divided by the total number of EYFP-labeled cells. ND, Not detected. Note that ROR $\beta$ was hardly detected in 1 DIV cortical slices.

$8 M, N)$. These results suggest that NRN1 and VGF promote dendritic growth of layer 4 stellate neurons but not of layer 5 pyramidal neurons.

To examine the combined effects of these two molecules on dendritic growth of stellate neurons, both proteins were added to the slice cultures from E13.5 transfected brains. The application of NRN1 and VGF also significantly increased the number of primary dendrites and the total length of dendrites of stellate cells (dendrite number, $6.79 \pm 0.41, n=19$ cells, $P<$ 0.01 ; total dendritic length, $1530 \pm 85.2 \mu \mathrm{m}, n=19$ cells, $P<$ 0.01 ), but the increases were not different from those for single application of either NRN1 or VGF $(p>0.05)$. Thus, it is unlikely that NRN1 and VGF have different downstream signaling pathways

\section{Survival of cortical neurons is enhanced by NRN1 and VGF}

In addition to dendritic growth, cell survival was also enhanced by NRN1 or VGF application in dissociated cortical cell culture. AcTub-positive cells are negative for cleaved caspase- 3 and free of pyknotic nuclei (Fig. 9D), indicating that they are survived neurons. Cell count analysis demonstrated that $\sim 25 \%$ of plated neurons survived at $7 \mathrm{DIV}$ without protein application. In contrast, the number of surviving neurons increased significantly in the presence NRN1 in a dose-dependent manner $\left(1276 \pm 202 \mathrm{cells} / \mathrm{cm}^{2}\right.$ for the control; $1662 \pm 392, p>0.05$ for $20 \mathrm{ng} / \mathrm{ml} ; 1902 \pm 124, P<0.05$ for 200 ng/ml; $1895 \pm 204, P<0.05$ for $2000 \mathrm{ng} / \mathrm{ml} ; n=4$ wells for each concentration) (Fig. 9A,B,E). Similarly, VGF application significantly increased the number of survived neurons after 1 week in culture (1251 \pm 59 cells $/ \mathrm{cm}^{2}$ for the control; $1585 \pm 171, p>0.05$ for $30 \mathrm{ng} / \mathrm{ml} ; 1800 \pm 103, P<0.01$ for $300 \mathrm{ng} / \mathrm{ml} ; 1823 \pm 133, P<$ 0.01 for $3000 \mathrm{ng} / \mathrm{ml}, n=4$ wells for each concentration) (Fig. $9 A, C, F)$. Thus, NRN1 and VGF promoted the survival of developing cortical neurons in vitro. 

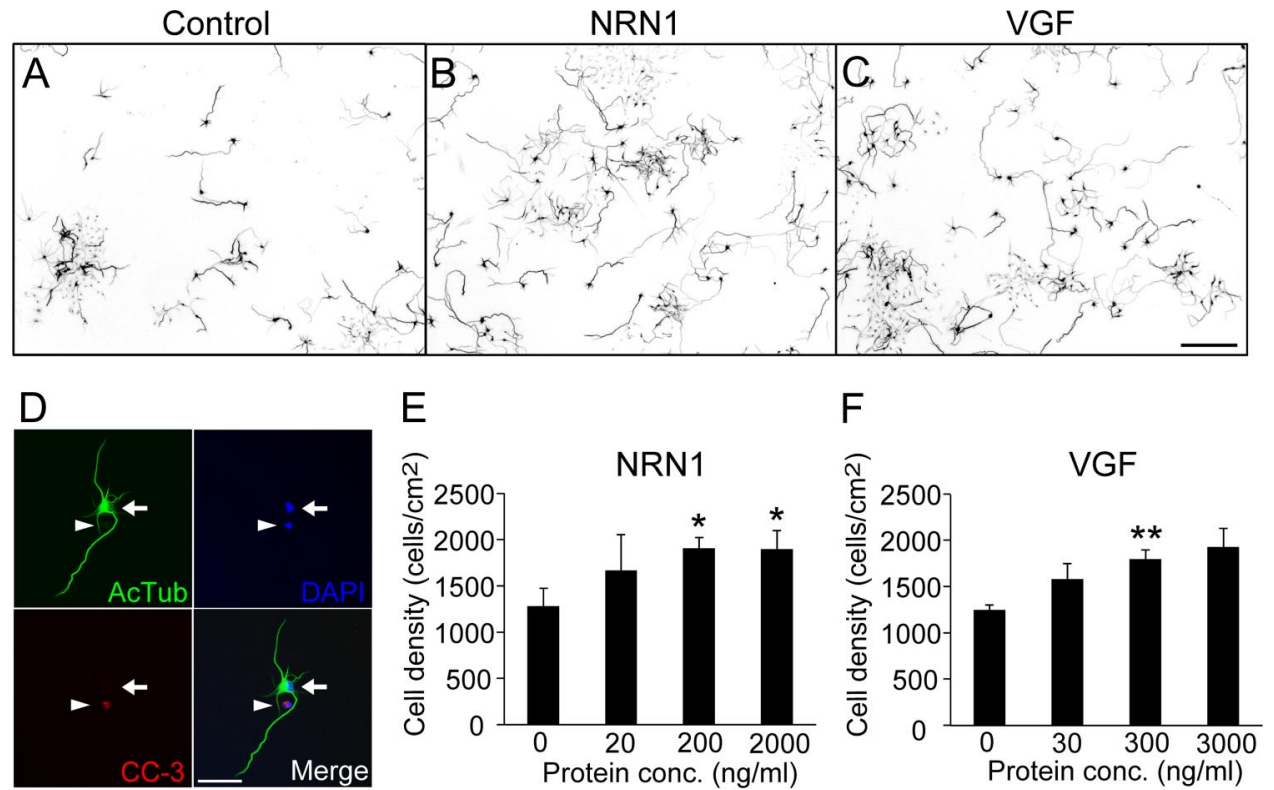

Figure 9. NRN1 and VGF enhance survival of cortical neurons. $\boldsymbol{A}-\boldsymbol{C}$, Dissociated cortical cells were cultured for 7 days in the absence $(\boldsymbol{A})$ and presence of either NRN1 $(\boldsymbol{B})$ or VGF $(\boldsymbol{C})$ and were visualized by immunostaining with anti-AcTub. D, Immunostaining for cleaved caspase-3 (CC-3) together with AcTub. AcTub-positive cells are negative for CC-3 (arrows). Conversely, CC-3-positive cells are negative for AcTub and exhibit pyknotic nucleus (arrowheads). $\boldsymbol{E}, \boldsymbol{F}$, Quantitative analysis showed that the application of NRN1 $(\boldsymbol{E})$ or VGF $(\boldsymbol{F})$ significantly increased the density of AcTub-positive survived neurons at 7 DIV. Scale bars: $\boldsymbol{A}-\boldsymbol{C}, 300 \mu \mathrm{m} ; \boldsymbol{D}, 100 \mu \mathrm{m} .{ }^{*} P<0.05,{ }^{* *} P<0.01, t$ test. conc., Concentration.
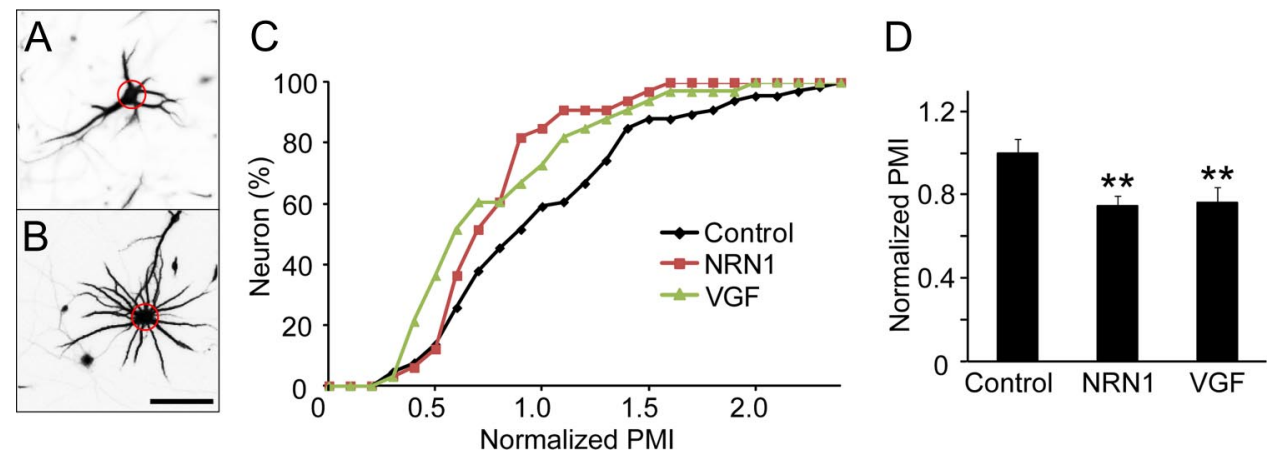

Figure 10. NRN1 and VGF increase the population of multipolar neurons in cortical cell culture. Morphological analysis was performed for cortical neurons at 14 DIV. $A, B, A$ typical pyramidalshaped cell $(\boldsymbol{A})$ and a multipolar cell $(\boldsymbol{B})$ were visualized by immunostaining with anti-MAP2 antibody. Each normalized PMI value $(\boldsymbol{A}, 1.20 ; \boldsymbol{B}, 0.38)$ was calculated using a sampling circle (red). $\boldsymbol{C}$, Cumulative frequency distribution of normalized pyramidal morphology index, PMI, in the control and in the presence of either NRN1 or VGF. NRN1 and VGF application increased the population of neurons that have smaller PMIs. $\boldsymbol{D}$, Average PMI values in the control, NRN1, and VGF. Scale bar, $\boldsymbol{A}, \boldsymbol{B}, 100 \mu \mathrm{m} .{ }^{* *} P<0.01, t$ test.

\section{NRN1 and VGF increased proportion of multipolar neurons in cortical cell culture}

To further examine which cell type is more affected in survival, morphological analysis of cortical neurons was performed in dissociated cell culture. Pyramidal neurons exhibit a unipolar morphology characterized by the presence of a long thick apical dendrite, whereas spiny stellate neurons show a multipolar morphology with multiple dendrites (Staiger et al., 2004). Based on these features, pyramidal morphology index analysis was adopted on the cultured cortical neurons, whose dendritic morphology was visualized by immunostaining with anti-MAP2 antibody at 14 DIV. The PMI is calculated by dividing the width of the widest neurite by the number of the neurites that intersect a circle drawn around a cell body (see Materials and Methods). Consequently, multipolar neurons have smaller PMI values than pyramidalshaped neurons (Fig. 10A,B). Cumulative distribution of normalized PMI showed that the proportion of neurons with smaller PMIs was increased by NRN1 and VGF application (Fig. 10C). Consistently, cortical neurons cultured in the presence of either
NRN1 or VGF have a smaller normalized PMI value $(1.00 \pm 0.07$, $n=66$ cells for the control; $0.74 \pm 0.05, n=33$ cells, $P<0.01$ for $200 \mathrm{ng} / \mathrm{ml}$ of NRN1; $0.76 \pm 0.07, n=33$ cells, $P<0.01$ for 300 $\mathrm{ng} / \mathrm{ml}$ of VGF) (Fig. 10D). Thus, NRN1 and VGF increased the proportion of multipolar neurons.

\section{Cell fate of cortical neurons is not affected by NRN1 or VGF}

The above result raises the possibility that the thalamus-derived factors may also affect cell fate. To test this possibility, we investigated whether NRN1 and VGF application could alter cell type during culturing by performing time-lapse analysis in the organotypic cultures from neonatal mice. Cell morphology was imaged before and 6 days after the application of NRN1 or VGF at 1 DIV (Fig. 11A). Sparse labeling allowed us to analyze, at 7 DIV, morphology of EYFP-labeled cells that had been observed at 1 DIV. Although it was not easy to distinguish cell types at 1 DIV, most neurons in the cortical plate were either unipolar, with a long process, or multipolar, with several short neurites (Fig. $11 B, C$, top panels). 

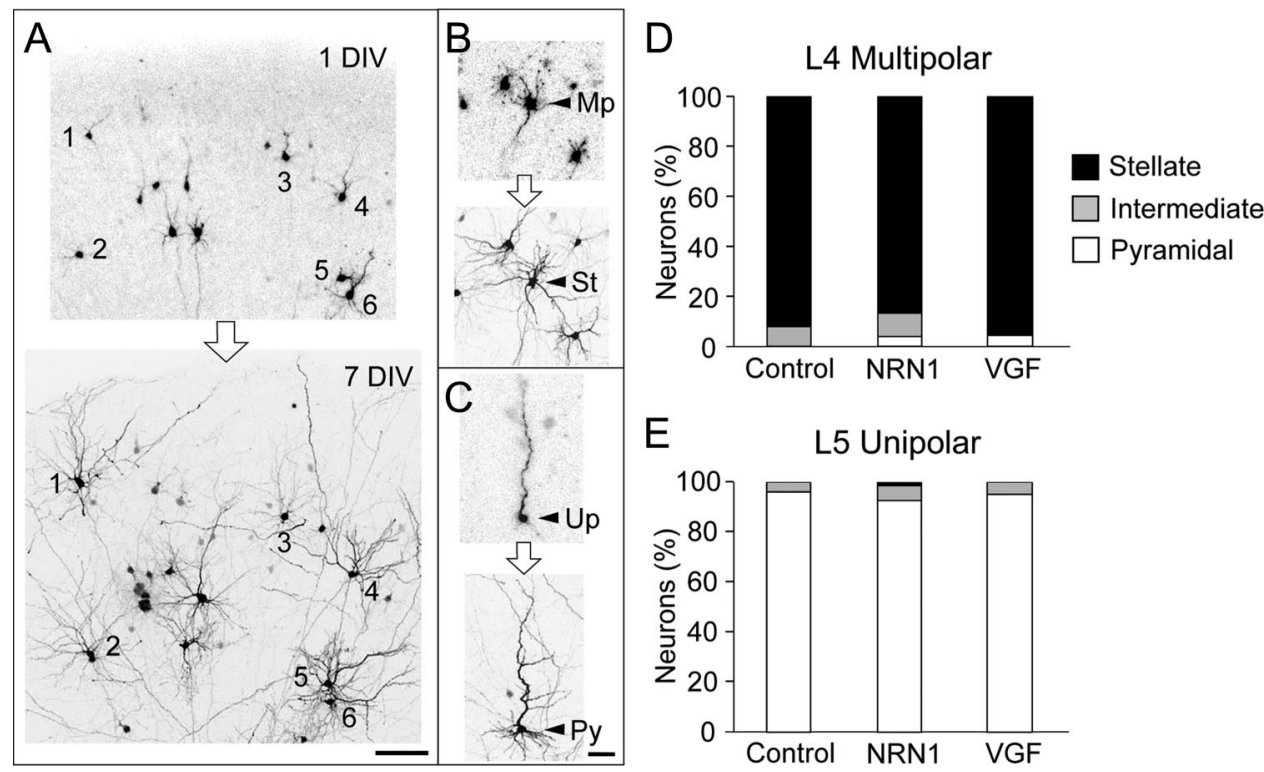

Figure 11. NRN1 and VGF do not markedly affect cell fate of cortical neurons. $A$, Time-lapse imaging of labeled neurons in slice culture at $1 \mathrm{DIV}$ and $7 \mathrm{DIV}$. Each number represents the same neuron at the two time points. B, C, Typical examples of a neuron differentiating from multipolar morphology (Mp) to a stellate cell (St) (B), and from unipolar morphology (Up) to a pyramidal cell (Py) (C). $\boldsymbol{D}$, The histogram shows the proportions of multipolar cells that became stellate (black), pyramidal (white), and intermediate (gray) cell types after culturing. $\boldsymbol{E}$, The proportions of unipolar cells that became stellate (black), pyramidal (white), and intermediate (gray) cell types after culturing. Scale bars: $A, 100 \mu \mathrm{m} ; \boldsymbol{B}, \boldsymbol{C}, 50 \mu \mathrm{m}$.

Most E13.5 electroporated cells had several short neurites even at 1 DIV. Immunohistochemical analysis using layer markers showed that cells were mostly positive for CUX1 but negative for ER81 (22/25 cells for CUX1; 1/30 cells for ER81) (Table 2). This satisfies the necessary condition for layer 4 stellate cells. Time-lapse imaging at 7 DIV showed that most of the cells having several short neurites at 1 DIV (26/28 cells) differentiated into stellate cells with multiple dendrites in the normal culture medium (Fig. $11 \mathrm{~B}, D$ ). The remaining two cells exhibited an intermediate morphology between stellate and pyramidal after culturing. On the other hand, E12.5 electroporated cells exhibited the unipolar morphology at 1 DIV. These unipolar cells were almost negative for CUX1 but partially positive for ER81 (1/24 cells for CUX1; 16/46 cells for ER81) (Table 2), which indicates that they are not destined for upper layer cells, including layer 4 stellate neurons. Timelapse imaging at 7 DIV revealed that all unipolar cells examined $(n=25)$ became typical pyramidal cells with apical dendrites in the normal culture medium (Fig. 11C,E), except for only one cell that exhibited intermediate morphology (Fig. $11 E)$.

We found that NRN1 or VGF application did not notably change the characteristics of cellular development. In fact, the cells having several short neurites at 1 DIV mostly became obvious multipolar neurons identified as stellate cells in the presence of either NRN1 or VGF (27/31 cells for NRN1 and $26 / 27$ for VGF) (Fig. $11 D$ ). Likewise, $>92 \%$ of the unipolar cells became typical pyramidal cells during culturing with each of these proteins (60/65 cells for NRN1 and 38/40 for VGF) (Fig. 11E). These results suggest that the thalamus-derived molecules NRN1 and VGF have negligible effect on the cell fate of cortical neurons.

\section{Discussion}

In this study, we identified thalamus-specific genes using microarray analysis and a subtraction cDNA library. Throughout further analyses we selected NRN1 and VGF as molecules that may affect cortical cell development by being expressed specifically in sensory thalamic nuclei and transported to thalamic axon terminals. In vitro analyses with dissociated cell culture demonstrated that NRN1 and VGF promoted dendritic growth of cortical neurons. Organotypic slice cultures further showed that NRN1 and VGF specifically promote dendritic growth of stellate neurons. In addition, survival of multipolar neurons was increased by these molecules without affecting cell fate. Taken together, these findings suggest that thalamus-derived NRN1 and VGF promote the dendritic growth and survival of a subset of cortical neurons.

\section{Identification of thalamus-specific extracellular molecules}

Previous studies have demonstrated that NRN1 and VGF are expressed in the developing thalamus in cats and rats, respectively (Lombardo et al., 1995; Corriveau et al., 1999). Our present study with comprehensive molecular screening and functional assay clearly demonstrates that NRN1 and VGF are the secretory molecules that are most specifically expressed in developing sensory thalamic nuclei in rodents, are transported to axonal tips, and can affect cortical cell development. In addition to NRN1 and VGF, we also identified eight secretory and membrane-bound ligand molecules that are specifically expressed in the thalamus at early postnatal stages, although their molecular characteristics do not meet the present criteria. Few of those genes overlapped with those identified by two previous studies in which gene expression profiles were compared between the thalamus and cortex (Kawasaki et al., 2004; Murray et al., 2007). This may be due to differences in the developmental stage and the species of animals examined. One striking feature of this study is that the identified thalamus-specific genes were mostly expressed in particular thalamic nuclei, notably the dLGN (Fig. 2, Table 1). Expression of Tmem 192 was restricted to the dLGN, which suggests properties that are unique to each thalamic nucleus. Furthermore, the ma- 
jority (Nrn1, Vgf, Wnt2b, and others) were expressed in multiple sensory thalamic nuclei, including the dLGN, VB, and MG, rather than in a single nucleus. This also implies that sensory thalamic nuclei have common molecular properties. Another feature is that the genes that showed specific expression in single or multiple sensory thalamic nuclei showed faint expression in the motor thalamic nucleus, the ventral anterior lateral nucleus (Fig. 2A,B). This may reflect different molecular organization between sensory and motor thalamic nuclei. Thus, the expression analyses not only uncovered thalamus-specific molecules in postnatal rodent brain, but also shed light on the molecular organization of developing thalamic nuclei.

\section{The role of thalamic axon-derived molecules in cortical development}

$\mathrm{Nrn} 1$ was originally identified as one of the plasticity-related genes (Nedivi et al., 1993) and has been demonstrated to promote neurite growth and cell survival of cortical neurons (Putz et al., 2005; Fujino et al., 2008). Furthermore, NRN1 has been shown to influence dendritic growth in the frog nervous system (Nedivi et al., 1998). VGF, a neurotrophin-inducible neuropeptide, has also been shown to enhance cell proliferation of hippocampal neurons (Thakker-Varia et al., 2007). The present detailed analyses demonstrated that NRN1 and VGF can enhance dendritic growth and cell survival of a subset of mammalian neocortical neurons.

Previous studies have shown that NRN1 and VGF are distributed in retinal and thalamocortical axons, respectively (Lombardo et al., 1995; Nedivi et al., 1998). Our in vitro and in vivo findings further demonstrate that these molecules are transported to thalamocortical axon terminals. Taking into consideration that both proteins are secreted substances, it is likely that NRN1 and VGF can be released from thalamocortical axon terminals and act on cortical cells. In other nervous systems, axon-derived molecules have been shown to regulate target cell differentiation. Agrin, for example, is secreted from motor neuron axons and induces assembly of postsynaptic components in muscular cells (Sanes and Lichtman, 2001), while Sonic hedgehog is secreted from retinal axons and induces cell proliferation in the visual center of Drosophila (Huang and Kunes, 1996). In this study, we demonstrate for the first time that NRN1 and VGF have such an anterograde influence in the mammalian brain.

Another intriguing aspect of NRN1 and VGF is their dendrite growth-promoting actions on a particular cell type. In this context, neurotrophic factors including BDNF and NT-3 have been shown to regulate dendritic growth of cortical pyramidal neurons (McAllister et al., 1995), but there are no reports regarding molecules that regulate dendritic growth of spiny stellate neurons. Our findings show clearly that NRN1 and VGF action is specific to spiny stellate cells. However, it is unlikely that these factors affect fate determination, as cell type conversion was not observed in the time-lapse study. NRN1 and VGF may regulate the development of postmitotic neurons but not progenitor cells, as is the case with BDNF and NT-3.

Dissociated cell culture showed that NRN1 and VGF promote not only dendritic growth but also cell survival. This result further indicates that the proportion of multipolar cells is increased in the presence of NRN1 or VGF (Fig. 10). Together with the result from the organotypic culture study, these two proteins are likely to promote the survival of stellate neurons rather than pyramidal neurons. Thus, the thalamusderived molecules NRN1 and VGF can specifically promote both survival and dendritic growth of spiny stellate neurons. Indeed, previous study has shown that thalamic ablation leads to reduction in the number of layer 4 neurons in the target cortex (Windrem and Finlay, 1991). NRN1 and VGF may mediate thalamic influence on the survival of layer 4 neurons. Since $N r n 1$ and $V g f$ are strongly expressed in sensory thalamic nuclei, they affect spiny stellate neurons preferentially in the axonal target region, layer 4 of the primary sensory areas. This is consistent with the fact that layer 4 is thicker and enriched with spiny stellate neurons in the primary sensory areas.

We have recently demonstrated that Netrin- 4 is expressed in developing thalamic cells as well as in layer 4 cells themselves at perinatal stages and may contribute to survival of layer 4 neurons (Takemoto et al., 2011). NTNG1, which is broadly expressed in the thalamus, has also been reported to be localized in thalamocortical axon terminals (Lin et al., 2003) and has neurite outgrowth-promoting activity in cortical cells (Nakashiba et al., 2000). We also observed an increase in the number of primary dendrites after application of NTNG1 in cortical cell culture (data not shown). NTNG1 may thus affect cortical cell differentiation broadly in the cortex as a thalamic axon-derived extrinsic molecule. Taken together, these observations suggest that survival and morphological differentiation of layer 4 stellate neurons are regulated by several thalamic axon-derived factors, including these molecules in addition to NRN1 and VGF.

We propose the following scenario for cortical development under the influence of thalamic axon-derived molecules that could be included in the protocortex hypothesis (O'Leary, 1989). During development, thalamic axons extend from sensory thalamic nuclei and travel to the cortex. After invading the cortical plate, they stop and form elaborated branches mainly in layer 4 of their target areas, where they contact with neurons to make specific neural connections, including synapse formation (Lopez-Bendito and Molnar, 2003). During this period, NRN1 and VGF are secreted from the thalamic axons and promote cell survival and dendritic growth of spiny stellate neurons in layer 4; that is, stellate neurons persist preferentially, and their dendritic morphology matures, particularly in the primary sensory areas. Furthermore, they may also be involved in neuropil formation by contributing to synaptic maturation and stabilization (Alder et al., 2003; Fujino et al., 2011). Consequently, layer 4 in primary sensory areas develops with differentiated spiny stellate neurons. This laminar organization is a unique characteristic of the cytoarchitecture of mature primary sensory areas.

In summary, our results demonstrate that NRN1 and VGF, which are specifically expressed in sensory thalamic nuclei, can be transported to axon terminals and promote the survival and dendritic growth of spiny stellate neurons. These molecules may contribute to the laminar configuration of the neocortex as extrinsic factors that are released from thalamic axons.

\section{References}

Ajioka I, Nakajima K (2005) Birth-date-dependent segregation of the mouse cerebral cortical neurons in reaggregation cultures. Eur J Neurosci 22:331-342. CrossRef Medline

Alcamo EA, Chirivella L, Dautzenberg M, Dobreva G, Fariñas I, Grosschedl R, McConnell SK (2008) Satb2 regulates callosal projection neuron identity in the developing cerebral cortex. Neuron 57:364-377. CrossRef Medline

Alder J, Thakker-Varia S, Bangasser DA, Kuroiwa M, Plummer MR, Shors TJ, Black IB (2003) Brain-derived neurotrophic factor-induced gene ex- 
pression reveals novel actions of VGF in hippocampal synaptic plasticity. J Neurosci 23:10800-10808. Medline

Armentano M, Chou SJ, Tomassy GS, Leingärtner A, O’Leary DD, Studer M (2007) COUP-TFI regulates the balance of cortical patterning between frontal/motor and sensory areas. Nat Neurosci 10:1277-1286. CrossRef Medline

Bedogni F, Hodge RD, Elsen GE, Nelson BR, Daza RA, Beyer RP, Bammler TK, Rubenstein JL, Hevner RF (2010) Tbrl regulates regional and laminar identity of postmitotic neurons in developing neocortex. Proc Natl Acad Sci U S A 107:13129-13134. CrossRef Medline

Bishop KM, Goudreau G, O'Leary DD (2000) Regulation of area identity in the mammalian neocortex by Emx2 and Pax6. Science 288:344-349. CrossRef Medline

Caceres A, Banker G, Steward O, Binder L, Payne M (1984) MAP2 is localized to the dendrites of hippocampal neurons which develop in culture. Brain Res 315:314-318. Medline

Catalano SM, Robertson RT, Killackey HP (1996) Individual axon morphology and thalamocortical topography in developing rat somatosensory cortex. J Comp Neurol 367:36-53. CrossRef Medline

Caviness VS Jr, Frost DO (1980) Tangential organization of thalamic projections to the neocortex in the mouse. J Comp Neurol 194:335-367. CrossRef Medline

Chen B, Wang SS, Hattox AM, Rayburn H, Nelson SB, McConnell SK (2008) The Fezf2-Ctip2 genetic pathway regulates the fate choice of subcortical projection neurons in the developing cerebral cortex. Proc Natl Acad Sci U S A 105:11382-11387. CrossRef Medline

Corriveau RA, Shatz CJ, Nedivi E (1999) Dynamic regulation of cpg15 during activity-dependent synaptic development in the mammalian visual system. J Neurosci 19:7999-8008. Medline

Cubelos B, Sebastián-Serrano A, Kim S, Moreno-Ortiz C, Redondo JM, Walsh CA, Nieto M (2008) Cux-2 controls the proliferation of neuronal intermediate precursors of the cortical subventricular zone. Cereb Cortex 18:1758-1770. CrossRef Medline

Dhande OS, Hua EW, Guh E, Yeh J, Bhatt S, Zhang Y, Ruthazer ES, Feller MB, Crair MC (2011) Development of single retinofugal axon arbors in normal and beta2 knock-out mice. J Neurosci 31:3384-3399. CrossRef Medline

Ferri RT, Levitt P (1995) Regulation of regional differences in the differentiation of cerebral cortical neurons by EGF family-matrix interactions. Development 121:1151-1160. Medline

Fujino T, Wu Z, Lin WC, Phillips MA, Nedivi E (2008) cpg15 and cpg15-2 constitute a family of activity-regulated ligands expressed differentially in the nervous system to promote neurite growth and neuronal survival. J Comp Neurol 507:1831-1845. CrossRef Medline

Fujino T, Leslie JH, Eavri R, Chen JL, Lin WC, Flanders GH, Borok E, Horvath TL, Nedivi E (2011) CPG15 regulates synapse stability in the developing and adult brain. Genes Dev 25:2674-2685. CrossRef Medline

Fukuchi-Shimogori T, Grove EA (2001) Neocortex patterning by the secreted signaling molecule FGF8. Science 294:1071-1074. CrossRef Medline

Grove EA, Fukuchi-Shimogori T (2003) Generating the cerebral cortical area map. Annu Rev Neurosci 26:355-380. CrossRef Medline

Hand R, Bortone D, Mattar P, Nguyen L, Heng JI, Guerrier S, Boutt E, Peters E, Barnes AP, Parras C, Schuurmans C, Guillemot F, Polleux F (2005) Phosphorylation of Neurogenin 2 specifies the migration properties and the dendritic morphology of pyramidal neurons in the neocortex. Neuron 48:45-62. CrossRef Medline

Hevner RF (2007) Layer-specific markers as probes for neuron type identity in human neocortex and malformations of cortical development. J Neuropathol Exp Neurol 66:101-109. CrossRef Medline

Hevner RF, Daza RA, Rubenstein JL, Stunnenberg H, Olavarria JF, Englund C (2003) Beyond laminar fate: toward a molecular classification of cortical projection/pyramidal neurons. Dev Neurosci 25:139-151. CrossRef Medline

Huang Z, Kunes S (1996) Hedgehog, transmitted along retinal axons, triggers neurogenesis in the developing visual centers of the Drosophila brain. Cell 86:411-422. CrossRef Medline

Hughes HC (1977) Anatomical and neurobehavioral investigations concerning the thalamo-cortical organization of the rat's visual system. J Comp Neurol 175:311-336. CrossRef Medline

Kageyama GH, Robertson RT (1993) Development of geniculocortical pro- jections to visual cortex in rat: evidence early ingrowth and synaptogenesis. J Comp Neurol 335:123-148. CrossRef Medline

Kawasaki H, Crowley JC, Livesey FJ, Katz LC (2004) Molecular organization of the ferret visual thalamus. J Neurosci 24:9962-9970. CrossRef Medline

Lin JC, Ho WH, Gurney A, Rosenthal A (2003) The netrin-G1 ligand NGL-1 promotes the outgrowth of thalamocortical axons. Nat Neurosci 6:1270-1276. CrossRef Medline

Lombardo A, Rabacchi SA, Cremisi F, Pizzorusso T, Cenni MC, Possenti R, Barsacchi G, Maffei L (1995) A developmentally regulated nerve growth factor-induced gene, VGF, is expressed in geniculocortical afferents during synaptogenesis. Neuroscience 65:997-1008. CrossRef Medline

López-Bendito G, Molnár Z (2003) Thalamocortical development: how are we going to get there? Nat Rev Neurosci 4:276-289. CrossRef Medline

Mallamaci A, Muzio L, Chan CH, Parnavelas J, Boncinelli E (2000) Area identity shifts in the early cerebral cortex of Emx2-/- mutant mice. Nat Neurosci 3:679-686. CrossRef Medline

Maruyama T, Matsuura M, Suzuki K, Yamamoto N (2008) Cooperative activity of multiple upper layer proteins for thalamocortical axon growth. Dev Neurobiol 68:317-331. CrossRef Medline

Matsuda T, Cepko CL (2007) Controlled expression of transgenes introduced by in vivo electroporation. Proc Natl Acad Sci U S A 104:10271032. CrossRef Medline

McAllister AK, Lo DC, Katz LC (1995) Neurotrophins regulate dendritic growth in developing visual cortex. Neuron 15:791-803. CrossRef Medline

McConnell SK (1989) The determination of neuronal fate in the cerebral cortex. Trends Neurosci 12:342-349. CrossRef Medline

Miller MW (1986) Maturation of rat visual cortex. III. Postnatal morphogenesis and synaptogenesis of local circuit neurons. Brain Res 390: 271-285. CrossRef Medline

Molnár Z, Adams R, Blakemore C (1998) Mechanisms underlying the early establishment of thalamocortical connections in the rat. J Neurosci 18: 5723-5745. Medline

Molyneaux BJ, Arlotta P, Menezes JR, Macklis JD (2007) Neuronal subtype specification in the cerebral cortex. Nat Rev Neurosci 8:427-437. CrossRef Medline

Murray KD, Choudary PV, Jones EG (2007) Nucleus- and cell-specific gene expression in monkey thalamus. Proc Natl Acad Sci U S A 104: 1989-1994. CrossRef Medline

Nakashiba T, Ikeda T, Nishimura S, Tashiro K, Honjo T, Culotti JG, Itohara S (2000) Netrin-G1: a novel glycosyl phosphatidylinositol-linked mammalian netrin that is functionally divergent from classical netrins. J Neurosci 20:6540-6550. Medline

Nedivi E, Hevroni D, Naot D, Israeli D, Citri Y (1993) Numerous candidate plasticity-related genes revealed by differential cDNA cloning. Nature 363:718-722. CrossRef Medline

Nedivi E, Wu GY, Cline HT (1998) Promotion of dendritic growth by CPG15, an activity-induced signaling molecule. Science 281:18631866. CrossRef Medline

Nieto M, Monuki ES, Tang H, Imitola J, Haubst N, Khoury SJ, Cunningham J, Gotz M, Walsh CA (2004) Expression of Cux-1 and Cux-2 in the subventricular zone and upper layers II-IV of the cerebral cortex. J Comp Neurol 479:168-180. CrossRef Medline

O'Leary DD (1989) Do cortical areas emerge from a protocortex? Trends Neurosci 12:400-406. CrossRef Medline

O'Leary DD, Sahara S (2008) Genetic regulation of arealization of the neocortex. Curr Opin Neurobiol 18:90-100. CrossRef Medline

O'Leary DD, Chou SJ, Sahara S (2007) Area patterning of the mammalian cortex. Neuron 56:252-269. CrossRef Medline

Putz U, Harwell C, Nedivi E (2005) Soluble CPG15 expressed during early development rescues cortical progenitors from apoptosis. Nat Neurosci 8:322-331. CrossRef Medline

Ramón y Cajal S (1899) Comparative study of the sensory areas of the human cortex. In: Clark University 1889-1899 decennial celebration, pp 311335. Worcester, MA: Clark University.

Saito T, Nakatsuji N (2001) Efficient gene transfer into the embryonic mouse brain using in vivo electroporation. Dev Biol 240:237-246. CrossRef Medline

Sanes JR, Lichtman JW (2001) Induction, assembly, maturation and maintenance of a postsynaptic apparatus. Nat Rev Neurosci 2:791-805. CrossRef Medline

Schaeren-Wiemers N, André E, Kapfhammer JP, Becker-André M (1997) 
The expression pattern of the orphan nuclear receptor RORbeta in the developing and adult rat nervous system suggests a role in the processing of sensory information and in circadian rhythm. Eur J Neurosci 9:26872701. CrossRef Medline

Schlaggar BL, O'Leary DD (1991) Potential of visual cortex to develop an array of functional units unique to somatosensory cortex. Science 252: 1556-1560. CrossRef Medline

Staiger JF, Flagmeyer I, Schubert D, Zilles K, Kötter R, Luhmann HJ (2004) Functional diversity of layer IV spiny neurons in rat somatosensory cortex: quantitative morphology of electrophysiologically characterized and biocytin labeled cells. Cereb Cortex 14:690-701. CrossRef Medline

Tabata H, Nakajima K (2001) Efficient in utero gene transfer system to the developing mouse brain using electroporation: visualization of neuronal migration in the developing cortex. Neuroscience 103:865872. CrossRef Medline

Takemoto M, Hattori Y, Zhao H, Sato H, Tamada A, Sasaki S, Nakajima K, Yamamoto N (2011) Laminar and areal expression of unc5d and its role in cortical cell survival. Cereb Cortex 21:1925-1934. CrossRef Medline

Thakker-Varia S, Krol JJ, Nettleton J, Bilimoria PM, Bangasser DA, Shors TJ, Black IB, Alder J (2007) The neuropeptide VGF produces antidepressant- like behavioral effects and enhances proliferation in the hippocampus. J Neurosci 27:12156-12167. CrossRef Medline

Windrem MS, Finlay BL (1991) Thalamic ablations and neocortical development: alterations of cortical cytoarchitecture and cell number. Cereb Cortex 1:230-240. CrossRef Medline

Yamamoto N, Kurotani T, Toyama K (1989) Neural connections between the lateral geniculate nucleus and visual cortex in vitro. Science 245:192194. CrossRef Medline

Yamamoto N, Yamada K, Kurotani T, Toyama K (1992) Laminar specificity of extrinsic cortical connections studied in coculture preparations. Neuron 9:217-228. CrossRef Medline

Yoneshima H, Yamasaki S, Voelker CC, Molnár Z, Christophe E, Audinat E, Takemoto M, Nishiwaki M, Tsuji S, Fujita I, Yamamoto N (2006) Er81 is expressed in a subpopulation of layer 5 neurons in rodent and primate neocortices. Neuroscience 137:401-412. CrossRef Medline

Zhong Y, Takemoto M, Fukuda T, Hattori Y, Murakami F, Nakajima D, Nakayama M, Yamamoto N (2004) Identification of the genes that are expressed in the upper layers of the neocortex. Cereb Cortex 14:11441152. CrossRef Medline 